\title{
Classical Arabic and the reading traditions
}

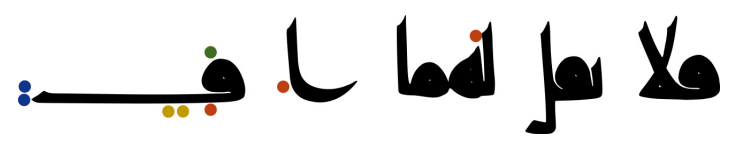

The Quran, Q17:23, in four different readings

\subsection{Introduction}

It is often stated that the Quran was composed in Classical Arabic, and that, moreover, the Quran served as a basis for Classical Arabic. These statements, taken at face value, seem to neatly wrap up our history of Arabic from the Islamic period onwards. The Quran introduced Classical Arabic as the main cultural language, and from that point forward all Islamic writing proceeded to imitate the linguistic standard set by the Quran. However, these claims have never been demonstrated, and I hope to show here that this definition is unsatisfactory. Already in the previous chapter we saw that the Sarabiyyah in the definition of the early grammarians is very broad, allowing for many different answers to what the language of the Quran really was. It is only in later times that what is considered Classical Arabic becomes strongly restricted. In this chapter, I will show that what was accepted as proper Arabic to recite the Quran in far exceeded the strict norms of the literary language that came to be accepted.

When we ask ourselves what the language of the Quran is, we should in turn ask ourselves “which Quran?" All too often, authors (often implicitly) assume that the Quranic text, in its full and ubiquitous form as we know it from the Cairo Edition of 1924, is the language in which it was pronounced by the prophet Muhammad. This text only represents the transmission of Pabu Yumar Hafṣ b. Sulayman b. al-Mugīirah al-Rasadī al-Bazzāz al-Kūfī (d. 18o AH/796 CE), colloquially known as Ḥaf̣̣, one of the transmitters of Pabū Bakr Yāṣim b. Pabì al-Nağūd al-Pasadī (d. 127 AH/745 CE ), ${ }^{1}$ colloquially known as Yāṣim. Hafṣ̣' trans-

1 N.в. Not 'Āṣim al-Ǧahdarī as the new translation of Nöldeke et. al. (2013) History of the Quran claims, which sadly has conflated these figures with identical death dates and isms, while they 
mission is by far the most dominant reading today, and linguistically his reading is rather close-but not identical—to Classical Arabic as it is described in our modern textbooks and, by extension, also very close to Modern Standard Arabic. ${ }^{2}$ This closeness may very well have given rise to the notion that the language of the Quran is more-or-less identical to the later norms of the literary language. But Hafș' reading is not the only reading of the Quran available, nor is it considered in any way more normative than other ones. Even today, there are millions of Muslims in Morocco and Algeria (and their diaspora in Europe) who recite the Quran according to the reading of ?abū SaYìd Guțmān b. SaYīd al-Mașrī (d. 197AH/812 CE) commonly known by his agnomen Warš, who was a transmitter of ?abū Ruwaym Nāfí b. Sabd al-Raḥmān b. Pabī NuYaym (d. $169 \mathrm{AH} / 785 \mathrm{CE})$. Warš's reading not only differs from Hafș in specific word choices, but also shows clear phonological and morphological differences with that of Ḥafș. To illustrate this, let us look at Q3:13 in both Ḥafș's and Warš's reading. ${ }^{3}$ I have marked every word that is pronounced differently between the two in bold, and provide an IPA transcription of both readings.

\section{Hāfṣ}

IPA

qad kāna lakum Pāyatun fỉ fịatayni t-taqatā firatun tuqātilu fì sabīli llāhi wa-?uxrā kāfiratun yarawna-hum mitlay-him ra?ya l-Sayn ${ }^{\mathrm{i}}$ \# [qadă ka:na lakum Pa:jatum: fi: fiPatajni t:aqata:

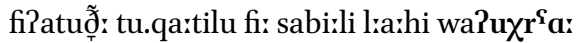
ka:firatuj̃ jarawnahum miӨlajhim $\mathrm{r}^{\mathrm{f}}$ a?ja liajn] wa-ḷ̣ahu yưayyidu bi-nașri-hī man yašāâu \#

Pinna fị d̄ālika la-Sibratan li-Pul̄̄ l-Pabșāir \#\# [wal ${ }^{\text {: }}$ a:hu juPaj:idu binas ${ }^{\Upsilon}$ rihi: maj jafa:i?

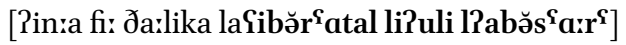

were separate in the original German. Replace 'Āṣim al-Jaḥdarī with 'Āṣim b. Abī al-Nağūd on pp. 414, n. 168; 457, n. 578; 469, n. 641; 470; 474, n. 23; 480; 483; 483, n, 88; 486; 491, n. 141; 492; 492, n. 147; 493; 494; pg. 500; 501; 507, n. 15 (twice); $5^{20}$ (thrice); 521; 522, n. 94; $5^{23}$ (four times); 524 (twice); 527; 530; 532 (five times); 533 (twice); 538; 539; 576; 594; 604. Replace Abū Bakr alȘiddīq (sic!) 'an 'Āṣim al-Jaḥdarī by 'Abū Bakr Šu'bah 'an 'Āṣim b. Abī al-Nağūd on p. 5 o1 n. 201.

2 It seems to me that this correlation is unlikely to be a coincidence. Hafș was the dominant transmission in the late Ottoman empire, and this is the time in which Modern Standard Arabic also started to be standardized. The historical development of the standard form of Classical Arabic, when it became standardized, and whether it was Hafș's transmission that influenced the formation of the standard or whether he rose to prominence because of his closeness to this standard is something that has not yet been adequately studied, and is outside the scope of this monograph.

3 Reconstructed on the basis of the description of al-Dānīs Taysīr, and matched with the pho- 
(cont.)

Warš

IPA

qad kāna lakumū Pāyatun fī fißatayni t-taqatā [qadă ka:na lakumu:: Pa:rjatumy: fi: fîatafiPatun tuqātilu fĩ sabīli llāhi wa-Puxrā kāfira- jni t:aqata: filatuợ: tuqa:tilu fi: sabi:li lia:hi

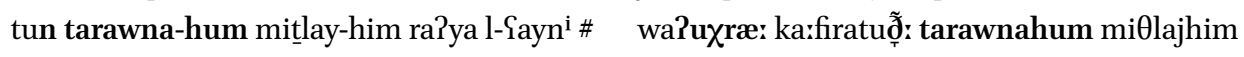
ría?ja liajn]

wa-ḷ̣ahu yuwayyidu bi-nașri-hī man yašā?u \#

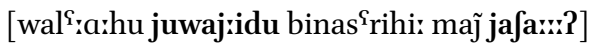

Pinna fī dālika la-Gibratan li-Pulī l-abṣā̉i \#\#

[?in:a fi: ða:lika laYibə̆ratal li?uli labə̆s'ææ::r]

In terms of the specific wording, the two readings are nearly identical. The only difference is that Hafș reads yarawna-hum mitlay-him ra?ya l-fayn "they see them as being twice their (number) by their own vision" whereas Warš reads tarawna-hum "you see them as ...".

The morphological and phonetic differences of Warš compared to Hafș, however, are much more numerous.

- Warš lengthens the plural pronouns -kum, -hum, Pantum, hum, -tum with an extra $\bar{u}$ whenever it is directly followed by a word that starts with a ? (lakumū).

- Warš replaces the ? with a glide whenever it is the first root consonant and not word-initial (yuwayyidu).

- Warš and Hafṣ (and all other readers) agree that a long vowel $\bar{a}, \bar{\imath}, \bar{u}$ should be pronounced overlong whenever a $?$ follows. But Warš also pronounces the vowel overlong whenever the ? precedes these long vowels (?āyatun).

- The overlong vowel in Warš recitation is pronounced significantly longer than that of Hafṣ (e.g. yašā?).

- Warš, as a rule, has a distinction between two vowels that are merged to $\bar{a}$ for Hafṣ. Whenever this vowel is written with a $y \bar{a}$ ? - pointing to its etymological origin-it is pronounced as $\bar{a}($ ?uxrä).

- The sequence $r a$ is pronounced emphatically by Hafṣ and the other canonical readers, with the exception of Warš who reads it without emphasis if $i$ stands in the previous syllable and no emphatic consonants intervene.

netics through the recitations of Muhammad Șiddīq el-Minšāwī (Ḥaf̣s) and al-Yuyūn al-Kūšī (Warš), https://www.nquran.com/ar/index.php?group=ayacompare\&sora=3\&aya=13. 
- The sequence $\bar{a} r i$ is raised to $\bar{a} r i$ if the $-i$ is the genitive case vowel (l-abșärri) by Warš.

- For Warš, if a word that starts with a glottal stop is preceded by a word that ends in a consonant, or the definite article, the glottal stop is dropped. Preceding long vowels are still shortened before the definite article, as if it were a two-consonant cluster (l-abșäri).

- A final effect in Waršs reading not found if one pauses on yašăa (an optional pause) but present if one does not is the dropping of the second $?$ whenever two of those meet with one short vowel in between across word boundaries. Thus yašā?u Pinna would be pronounced yaš̄̄? inna [ja jamiu.in:a].

This overview gives a taste of some of the pervasive linguistic effects of the different readings. They can have variations in their phonological vowel systems, their phonetic realization, morphology and indeed specific wording. While differences in the specific wording are significantly less common than those concerning the linguistic details, these still concern thousands of words. As for the linguistic details, the vast majority of the verses are affected in some way by changes in sound and form of the Quranic readings.

Today, ten readings are accepted as canonical (Nasser 2013a; Nöldeke et al. 2013, 529 ff.). The first seven of these were canonized by the end of the 3 rd or beginning of the 4th century AH when Ibn Muğanhid (d. $324 \mathrm{AH} / 936 \mathrm{CE}$ ) wrote his Kitāb al-SabSah fi al-Qiräăt. This is the earliest extant book on the readings and probably the first to make a real effort to restrain the number of readings that existed in this period. ${ }^{4}$ However, for these seven readers, Ibn Muğāhid reports no less than 49 immediate transmitters. Today, only two transmission paths for each of the canonical readers are considered canonical (thus making it 14 transmissions in total; not all these paths are immediate transmitters). This "two-Rāwi Canon" seems to have been first introduced by Pabū alṬayyib b. Ġalbūn (d. 389AH/998 CE), but really took off when Pabū Samr al-Dānī (d. 444AH/1052-1053 CE) wrote his Al-Taysìrfı́ al-Qirā?āt al-Sabৎ, and Al-Šāțibì (d. $590 \mathrm{AH} / 1194 \mathrm{AH})$ summarized it into a didactic poem popularly known as al-Šățibiyyah. These two works are still dominant in the teaching of the seven readings today (Nasser 2013a).

The seven readers are associated with five important districts, one each for Medina, Mecca, Damascus and Basra and three for Kufa. The seven readers and their transmitters are as follows (after Watt and Bell 1991, 49):

4 There were almost certainly several works on the readings before ibn Muğāhid, such as Pabū Gubayd's and al-Ṭabarì's, but these appear to have been lost (Nasser 2013b, $36 \mathrm{ff}$.). 


\begin{tabular}{|c|c|c|c|}
\hline \multirow{2}{*}{$\begin{array}{l}\text { District } \\
\text { Medina }\end{array}$} & \multirow{2}{*}{$\begin{array}{l}\text { Reader } \\
\text { Nāfî (d. 169/785) }\end{array}$} & \multicolumn{2}{|c|}{ Transmitters } \\
\hline & & Warš (d. 197/812) & Qālūn (d.22o/835) \\
\hline Mecca & Ibn Katīir (d. 12o/738) & al-Bazzī (d. 25o/864) & Qunbul (d. 291/904) \\
\hline Damascus & Ibn Yāmir (d. 118/736) & Hišām (d. 245/859) & Ibn Dakwān (d. 242/856) \\
\hline Basra & Pabū Samr (d. 154/770) & al-Dūrī (d. 246/86o) & al-Sūsī (d. 261/874) \\
\hline Kufa & Sāṣim (d.127/745) & Hafṣ (d. 18o/796) & ŠuYbah (d. 193/8og) \\
\hline Kufa & Hamzah (d. 156/773) & Xalaf (d. 229/844) & Xallād (d. 220/835) \\
\hline Kufa & al-Kisā?ī (d. 189/8o4) & al-Dūrī (d. 246/86o) & al-Layt (d. 240/854) \\
\hline
\end{tabular}

Some of these transmitters differ more from each other than others. The differences between Hafș and Šu $\mathrm{Ybah}$, for example, are so numerous that they disagree with one another more often than two separate readers like Hamzah and al-Kisā?î. While all other transmitters have differences as well, these transmitters agree with each other much more often, at least when it comes to the choice of specific words.

While Ibn Muğāhid tends to be seen as the 'canonizer' of the seven readers, his canonization only cemented the seven as taking up a central position in the canon, but did not necessarily prevent other readings from being added to the canon. Shortly after him, many works were written that added more and more readers to these initial seven. While many of these other readings have not reached general acceptance in the Muslim community, three more readers have eventually been accepted into the canon. The definitive canonization of the three after the seven is attributed to Ibn al-Ğazarī (d. $751 \mathrm{AH} / 135 \mathrm{O} \mathrm{CE})$ who adds the Basran Yåqūb al-Ḥaḍramī, Medinan Pabū Ğaffar and the Kufan Xalaf (the same Xalaf that is a transmitter of Hamzah) as extra eponymous readers, once again with two transmitters each, in his phenomenal work Našr al-Qirā?āt al-\{ašr.

Medina Pabū Ğâfar (d. 13o/747) Ibn Wardān (d. 16o/776) Ibn Ğammāz (d. 170/786)

Basra YaYqūb (d. 205/820) Ruways (d. 238/852) Rawh (d. 234/849)

Kufa Xalaf(d. 229/844) Pisḥāq (d. 286/899) Tidrīs (d. 292/905) 
In the Našr Ibn al-Ğazarī also records in detail a second path of the transmission of Warš, namely that of al-Paṣbahānī, which has significant differences with the one recorded already by al-Dānī, the path of al-?azraq.

When we see statements that claim that "the Koran established an unchanging norm for the Arabic language" (Thackston 1994, xii) or "the Koran [...] was none other than the poetic koine" (Rabin 1955, 24), this is not very informative. When we actually want to examine what this alleged unchanging norm looked like, we are confronted not with a single answer, but instead with more than twenty different ones. All of these readings differ in significant linguistic ways from what is now considered the standard and, moreover, contain linguistic features that not infrequently fall outside of the purview of the kind of linguistic variation that is described by the Arab grammarians.

In this chapter I will examine what the Quranic readings are, and what they are not. First, I will show that the readings cannot be considered dialects of Arabic or simply Classical Arabic with some dialectal specificities added onto them. Moreover, I will show that there is a high amount of purposeful artificiality to the linguistic practices present in the readings showing what must be considered a concerted effort to make the readings unusual, exotic and eloquent. As a result, I conclude that in terms of what the readings can tell us about the language of the Quran, they fail to give a consistent and uniform answer. As such, the readings cannot serve as the sole source to inform us about the language of the Quran.

\subsection{Reading or Recitation?}

The term qirā?ah, the Arabic name used for a reading tradition, is ambiguous, as it can mean both "recitation" or "reading". The first meaning might imply the readings (as I translate qirā?āt here) are a purely oral transmission of the Quran. Muslims today often envision the readings in such a way, seeing the canonical readings as unbroken and mass-transmitted (mutawātir) of the Quranic text from the prophet until today. ${ }^{5}$ In the early 2 oth century, Gotthelf Bergsträßer (Nöldeke et al. 2013, 472 ff.) already saw that this strict way of envisioning the readings as purely oral "recitations" is untenable, which led him to conclude that the Quranic consonantal text was in many cases primary to the readings

5 The view that the transmission of the Quran is tawätur seems to develop some significant time after the canonization of the readers. For an in-depth discussion on the emergence of view of tawātur of the readings see Nasser $(2013 \mathrm{~b})$. 
that exist. I follow him in this conclusion, but it is worth examining in detail some of the arguments in favour of seeing the readings being dependent on the written form of the text.

First of all, each and every canonical reading basically agrees with the Uthmanic rasm, something that is even deemed necessary for a reading to be considered valid (at least as early as al-Tabarī (d. 310/923), see Nasser 2013b, 45). Companion readings such as those reported for ?ubayy and Ibn Masfūd are considered invalid recitations in part because they do not agree with the rasm. If even well-respected companions of the prophet had readings that allowed for more oral variation than the Uthmanic readings, it is highly unlikely that so many different oral traditions just so happened to agree with the rasm. For example, Hamzah ultimately traces his reading back to the famous companion Ibn Maşūd (al-Dānī Taysìr, 9). Ibn Maşūd's reading does not agree with the rasm while Hamzah's reading does. The most likely explanation for this discrepancy is that Hamzah purposely changed his reading in order for it to agree with the rasm, rather than Ibn Maşūd having used two readings, one not agreeing with the rasm, and another one that just so happened to agree with the (not yet extant) rasm. ${ }^{6}$

Occasionally it is possible to envision those variant readings indeed have origins in a pre-existent oral tradition where the rasm, by accident, accommodated both readings. For example, in Q33:68 Yāșim is the only one to read wa-Palian-hum lainan kabiran "and curse them with great cursing", rather than wa-Palian-hum laSnan katiran "and curse them with many a curse." (Ibn alĞazarī, §3952). The difference between these two readings comes down to a difference in dotting in the word which could either be read katiran or kabiran, but these two readings are semantically and phonetically so close, that it does not seem unlikely that such variants could have existed in the oral transmission of the Quranic text before canonization, and by sheer accident happened to agree with the rasm when it was instated. However, there are other

6 See also the highly interesting work of Shahpasand \& Vahidnia (2018) who show that Hamzah and al-Kisā?ī overwhelmingly choose for reading verbs as masculine when the rasm allows both a masculine or feminine reading, which they convincingly argue is based on the fact

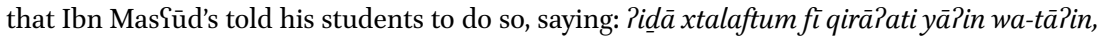

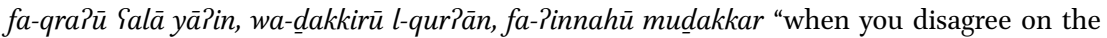
reading of a $y \bar{a}$ ? or a $t \bar{a}$ ? [of a prefix-conjugation verb] then read it with a $y \bar{a}$ ?, and make the Quran masculine, for it is masculine." In a highly engaging paper presented at the Reading the Rasm II symposium (3-5 December 2019, Berlin), Shahpasand further showed that especially Hamzah consistently chooses readings that agree with Ibn Masfūd's reading as much as the rasm could allow, even occasionally reading the consonantal skeleton in rather unintuitive ways in order to accommodate such readings. 
variants where the phonetics are rather different, and it is by coincidence that in the ambiguous script of Arabic they happen to be written the same. It is unlikely that these kinds of variants do not have their basis in the Uthmanic rasm. Some salient examples of this point are the following: و fa-tatabbatū 'proceed with caution!' (al-Kisā?ī; Hamzah; Xalaf), fa-tabayyanū 'be clear!' (the others) (Q4:94; Q49:6, Ibn al-Ǧazarī, § 2951); عص الحى yaqușșu l-ḥaqq 'he tells

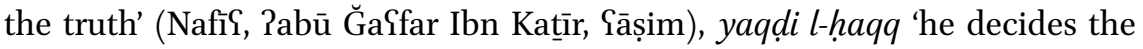
truth' (the others) (Q6:57; Ibn al-Ğazarī, § 3029); ; I lu tatlū 'recites, recounts' (alKisā?īi Ḥamzah; Xalaf) tablū 'tests' (the others) (Q10:3o; ibn al-Ğazarī, §3354). In such cases, the most likely explanation as to why the readers disagree is not that they were transmitting an oral transmission, but rather that the readers were confronted with an ambiguous rasm and interpreted it in two ways that both made semantic sense. ${ }^{8}$

A final point that shows that the readers are to a significant extent dependent on the written form of the text, can be gathered from the fact that the canonical readers all agree with the rasm of their respective regions. The tradition has it that when Uthman standardized and distributed the text, he had (at least) four copies of the text made, and distributed these to Medina, Basra, Kufa and Syria (most likely Homs, not Damascus ${ }^{9}$ ). This traditional account is corroborated by Quranic manuscripts, as it is clear that all Quranic manuscripts of the Uthmanic Text Type descend from a single archetype (van Putten 2019c) and we can indeed identify which of these four regional traditions a Quranic manuscript belongs to by comparing the differences in the rasm they have (Sidky 2021).

There are about 6o locations in the Quran, where these regional codices have a slightly different consonantal skeleton. The way that these variants are distributed form a perfect, uncontaminated, stemma (Cook 2004). When such regional difference in consonantal skeleton appears, it is consistently followed closely by the readers of these different regions. ${ }^{10}$ For example, the Syrian

$7 \quad$ For a discussion of this variant see Sadeghi (2013).

8 For a similar case where a direct interpretation of the rasm by one of the canonical readers can be observed is the reading of Hišām Yan ibn Yāmir who reads Pibrāhām and Pibrāhìm wherever the Archetypal QCT has برهي ابرهيم respectively (van Putten 2020b).

9 Sidky (2021).

10 There are a small number of exceptions to this general rule. Hafṣ Yan Yāṣim deviates from the Kufan Codex in Q36:35 reading Samilat-hu, instead of Samilat (Ibn al-Ǧazarī, §40o6) and Q43:71 taštahī-hi instead of taštahī (Ibn al-Ǧazarī, § 4169). Pabū Ğa9far in one case deviates from the Medinan rasm favouring the Syrian variant Q1o:22 yanšuru-kum over yusayyiru-kum (Ibn al-Ǧazarī, §3251). Pabū Yamr reads Q40:26 wa-Pin instead of ?aw Pin (Ibn al-Ǧazarī, §4101). 
codex exclusively has Q7:141 الحكك whereas the other codices have الحسك . This is reflected in the readings where the Syrian reader Ibn Yāmir reads ?anğa $\overline{-}-k u m$, whereas all other readers read Panğaynāa-kum (Ibn al-Ğazarī § 3137). Likewise, the Medinan and Syrian codices have Q5:54 ر w w where the Basran and Kufan codices have ; Ğaffar read this word as yartadid where the other readers read yartadda (Ibn al-Ğazarī § 2989).

The agreement of the readings with the rasm cannot be explained by an intentional accommodation of the rasm to already existing local oral traditions. Had this been the case, we would be unable to explain how the Syrian mușhaf shares all variants with the Medinan codex and not a single one with the Basran and Kufan codex, etc. So, whatever oral tradition existed was evidently subjected to a requirement to agree with the rasm rather than the rasm being updated to match the regional qirāe $\bar{a}$. It is for these reasons that we must think of the Quranic reading traditions as being just that, primarily readings of the rasm.

\subsection{Lack of Regular Sound Change}

Many differences among the readings come down to different interpretations of the meaning of the text, reading words differently which here and there can have significant impact on the meaning of a verse and the theology that flows from it. However, most of the differences do not come down to textual/interpretational differences, but rather involve linguistic differences. For example, while most readers read Salay-him 'upon them', Hamzah and Ya Yqūb read Salayhum and Ibn Kațīr, Rabū ĞaYfar and optionally Qālūn read it Salay-himū. These differences do not affect the meaning in any way, yet they are linguistically salient. These kinds of purely linguistic differences are what gives these readings their distinct flavour, and are the features that helps one most easily distinguish the different readings from one another.

As we saw already in the previous chapter, the Arab grammatical tradition records a vast amount of linguistic variation within the Sarabiyyah. This variation is often presented through clear and regular rules by these grammarians. Such reports seem to reflect actual sound changes that have taken place in the dialects of the Sarabiyyah, and the agreement of the descriptions between the different early grammarians seems to lend considerable confidence to at least the general dialect geography they sketch. The most comprehensive account of the grammarian reports of the linguistic variation of the farabiyyah is still the monumental work by Rabin (1951), which will serve to some extent as a 
basis for the following examination. However, because it is almost 70 years old now, there is some room for this work to be updated. Most importantly, an edition of one of the earliest accounts of the Arabic dialects has recently been published. At the time of Rabin's writing, this work was known to have existed, but no manuscript was known to have been preserved. This work is alFarrā?'s (d. 207/822) Kitāb fih Luġāt al-Quriān. As a student of al-Kisā?ī-the Quranic reader, grammarian and famous rival of Sībawayh ${ }^{11}$-al-Farrā? constitutes the earliest example of the Kufan school of grammar of which there are extant works available. It is now clear that an enormous amount of the dialectal data recorded by later grammarians is highly dependent on al-Farrā?'s work. This is often confirmed explicitly by later grammarians who cite either al-Farrā? or al-Kisā?ī (often on al-Farrā?'s authority) for many of the data they adduce.

In the following sections, we will examine some of the linguistic features reported for the Sarabiyyah, and we will focus primarily on the accounts of al-Farrā? and Sībawayh. While later grammarians may occasionally adduce features of the Arabic dialects not mentioned by either of these authors, the amount of such data that is relevant to the Quran seems rather more limited. Moreover, as we are interested in the Arabic of the time the Quran was composed, it seems worthwhile to stick to the secondary sources that are as close to this period as possible.

Rabin's $(1951,7)$ claim that "the grammarians of the Basrian school evinced little real interest in the dialects" and that "Sỉbawayh mentions mainly usages as were permissible in Arabic as he conceived it." gives perhaps too little credit to the monumental importance of Sïbawayh's work on Arabic. It is true that alKitāb has far fewer attributions of features of Arabic to different tribes than Lugāat al-Quriān, but this seems to a large extent dependent on genre. The express goal of al-Farrā?'s work was to record and classify all the different linguistic practices as they occur in the Quran, whereas Sïbawayh's is much more concerned with a description and explanation of the grammatical workings. Much of the variation described by al-Farrā? is likewise described by Sībawayh, but often lacking the explicit tribal attribution.

The profound influence that al-Farrā?'s work had on later grammarians and lexicographers in forming the classificatory framework in which variation of Arabic is understood may have led to the impression that that was the focus of the Kufans par excellence. As we will see, Sībawayh's work often does comment

11 He famously bested Sïbawayh in a debate known as al-Masialah al-Zunbüriyyah, which is said to have led to Sībawayh's untimely demise (Carter 2004, 13 f.). 
on dialectal uses, and when he does it more often than not coincides with the description of al-Farrā?, although the latter is generally more detailed.

As more or less contemporaneous grammarians of two different schools, ${ }^{12}$ finding the observations of the one grammarian corroborated by the other should help alleviate some of the unease a modern linguist might feel about the reliability of such accounts. While the Arab grammarians were certainly not interested in everyday speech, which must have already have developed significantly towards a form closer to the modern dialects as we know them today (see § 2.4), whatever these rival grammarians are describing and agreeing upon must have represented some linguistic reality.

Nevertheless, the following sections will not depend on the assumption that the Arab grammarians are necessarily reporting reliable data of the dialects: these sections will examine certain linguistic processes in their own right, regardless of what tribe they are attributed to. When phonetic sound changes take place in a natural language, these operate without exception. Thus, for example, English underwent a development where word-initial / kn-/ lost the $/ \mathrm{k} /$, and therefore all modern English words that are still written, through historical orthography with this cluster, all pronounce it simply with $/ \mathrm{n}-/$, e.g. knight, knee, knot, knead. Dutch, having not undergone this development retains and pronounces the $k$ in all of these places, as in knecht, knie, knot and kneden. It would be highly unexpected to find that some English words preserved the / $\mathrm{kn}-/$ pronunciation, or that only some Dutch words lost the /k-/. Regularity of sound change, also called "sound laws" is one of the fundamental principles of historical linguistics, and when such regularity fails to apply, and there is no obvious explanation for this, this is a strong indication that we are dealing with a significantly mixed literary register (Hock 1991, 34-51).

In the following sections, we will examine a number of sound changes that are described by the Arab grammarians as clear and regular sound laws that apply in some of the dialects. As we will see, in the Quranic reading traditions these fail to apply in a consistent way. Regardless of whether the attribution of such developments to different tribes by the grammarians is accurate, the failure of these developments to apply regularly is enough to show that the Quranic reading traditions do not make up consistent linguistic systems.

\subsubsection{Harmony of the Pronominal Suffixes}

According to al-Farrā? (Luġät, $10 \mathrm{f}$.), Qurayš and the people of the Hijaz had unharmonized Salay-hum, Salay-humā, Salay-hunna and Salay-hu/ü. The peo-

12 Al-Farrā? was born in 144/761 (Blachère EI ${ }^{2}$ al-Farra $\tilde{a}^{3}$ ), whereas Sïbawayh was presumably born around 135/752 (Carter 2004, 10). 
ple of Najd (i.e. Pasad, Qays and Tamīm) harmonized -hum, -humä, -hunna and

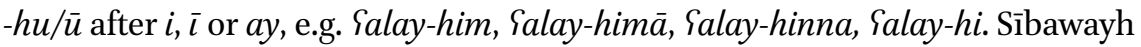
(IV, 195-198) likewise attributes the unharmonized forms to the Hijaz, and does not specify where the harmonized forms are used.

The majority of the readers read in the Najdi manner in terms of vowel harmony. This is the case for Yāșim, ibn Yāmir, Rabū Yamr, and even for the Hijazis ibn Katīir, Pabū Ğaffar, and Nāfiৎ. Clearly, the Quranic preferences do not correspond to the dialectal geography of the readers. There are two reciters who on occasion use the Hijazi form of the plural pronoun. For Hamzah this is lexically determined, he only recites Pilay-hum, laday-hum and Salay-hum without vowel harmony. Other cases of -ay- + 3pl.m. suffix undergo vowel harmony, e.g. ğannatay-him (Q34:16) and other pronouns do too, e.g. Salay-himā (e.g. Q2:229).

As for YaYqūb, he blocks vowel harmony of all the plural and dual pronouns (-hum, humā, hunna but not the singular pronoun $-h \bar{u} / u$ ) when $\bar{\iota}$ or ay precedes, but not when $-i$ precedes. While both of our early grammarians describe vowel harmony, neither of them seems to be aware of varieties that make a distinction in harmonization between $\bar{\imath}$ and $a y$ as against $i$ (Ibn al-Ǧazarī §112O). This kind of lexically or phonetically conditioned harmony is not described by the Arab grammarians and seems to be an innovation specific to the Quranic reading register (van Putten and Sidky forthcoming).

While neither grammarian assigns a dialectal identification to length disharmony and long plural pronouns, it is worth mentioning for completeness' sake the treatment of this among the readers as well. Ibn Katīir lacks vowel-length disharmony of the singular pronoun, and always has long pronouns, e.g. fih $\bar{\imath}$

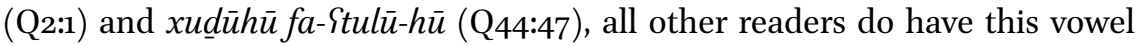
length disharmony (Ibn al-Ǧazarī § 1212). All readers (except Ibn Kațīr) also agree with al-Farrā?'s preference to pronounce the pronoun as short after a consonant such as minhu, rather than Sïbawayh's preference of $\operatorname{minh} \bar{u}$ (see $§$ 2.2.1).

Both Ibn Katīi and Pabū Ğaffar always use the long forms of the plural pronouns, humū, Salayhimū, Pantumū, etc., whereas Qālūn Yan NāfiY has the option to read with long or short pronouns (Ibn al-Ǧazarī §1122). Warš Yan Nāfí also makes use of the long pronouns but the conditioning will be discussed in more detail later in this chapter ( $\$ 3.6 .5)$. Thus, long pronouns seem to have been a typical feature of Hijazi recitation, but this does not align with the dialect geography as described by the Arab grammarians, who do not associate long pronouns with the Hijaz at all, and instead suggest it may be used in any dialect freely $(\S 2.2 .1)$. 


\subsubsection{Najdi Syncope}

One of the well-known features of the Najdi dialects compared to the dialects of the Hijaz, is their conditioned dropping of short high vowels (e.g. Rabin 1951, 97f.). In section $§ 2.2 .4$ we have discussed the treatment of this syncope as it is described by the Grammarians. From this description it becomes clear that both Sībawayh and al-Farrā? describe a regular linguistic development that spans a variety of different environments. While several readers have the syncope in some cases, they fail to apply regularly in all phonetically comparable environments. Even when it concerns a single class (such as nouns of the shape $\mathrm{CuCuC}$ syncopating to $\mathrm{CuCC}$ ), not a single reader treats these in a similar manner.

The following sections will look at six different environments in which this syncope is expected to take place when we follow the descriptions of the Arab grammarians. These will be discussed as separate categories as their treatment is different between the reading traditions.

\subsubsection{Syncope in fa-huwa, wa-hiya Etc.}

According to al-Farrā? and Sībawayh (see § 2.2.4.3), the third person singular pronouns huwa and hiya undergo syncopation of the $u / i$ whenever $w a-, f a-$ or la- would precede among the people of Najd, yielding wa-hwa, fa-hwa, lahwa, wa-hya, fa-hya, la-hya, whereas language the people of the Hijaz did not undergo this development, retaining fa-huwa, fa-hiya etc. (al-Farrā? Lugāat, 29).

Al-Farrā? adds that the Quranic reciters can use either the syncopated or the full form. This is in line with what we find. Qālūn San NāfiY, ?abū Yamr, alKisā?ī and Pabū ĞaSfar apply this syncope to the pronouns, while the rest opts for the Hijazi form (Ibn al-Ğazarī, §2641). ${ }^{13}$ Note that in terms of geographical distribution, no pattern appears, the Medinese readers, a single Basran and a single Kufan follow the Najdi pattern, while the others follow the Hijazi one.

\subsubsection{Fa/wa-li-yafYal > fa/wa-l-yafYal}

Sibawayh (IV, 151f.) and al-Farrā? (Lugia t, 29) mention that the li- of command may either syncopate or be maintained when $w a$ - or $f a$ - precedes, thus the Najdi manner is wa/fa-l-yaffal while the Hijazi manner is wa/fa-li-yaffal (see also §2.2.4.4). Sïbawayh explicitly mentions that those who say wa/fa-l-yaffal also reduce the vowel in wa-hwa, and wa-hya reduced it.

13 Al-Kisā?ī also reads țumma hwa (Q28:61) and Pabū Ğaffar yumilla hwa (Q2:282). 
This view had clearly shifted by the time of Ibn Muḡanhid (454), who discusses the reading wa-li-yadribna (Q24:31) 'let them (f.) draw' attributed to a non-canonical transmitter of Pabū Samr, Sabbās b. Faḍl. Ibn Muğāhid comments that this reading is as if it had the meaning of "in order to" (understanding it as wa-li- + subjunctive rather than wa-l(i)-+ apocopate), which semantically does not make sense in this context. Thus, Ibn Muḡāhid concludes "I don't know what this is" (wa-lā Padri mā hād $\bar{d}$ ). From this it is clear that that to Ibn Muğāhid the li-in such a context needs to be syncopated for it to designate the li- of command, and indeed all canonical readings have undergone this syncope, even those that do not syncopate wa-huwa and wa-hiya. The relation as drawn by the grammarians is therefore not applied regularly in the canonical readings.

The unsyncopated form, however, is still well-attested in non-canonical readings, both as they are reported in the literary tradition (see, for example Ibn Xālawayh muxtașar, 12, 17f., 18), as well as how they occur in early vocalized Quranic manuscripts. In BnF Arabe 33of, 34r (Q4:102), for example, we find clear evidence for fa-li-taqum, wa-li-ya?xudū, fa-li-yakūnū, wa-li-ta?ti, fali-yușallü and wa-li-ya?xudūu . It is therefore clear that we are not so much dealing with a fixed literary standard that preferred this syncopation, but instead this consensus developing in the time between the early Islamic period and the time that Ibn Muğāhid canonizes the seven readings.

\subsubsection{3 $\mathrm{CuCuC}>\mathrm{CuCC}$}

The people of the Hijaz pronounced singular and plural nouns of the shape $\mathrm{CuCuC}$, along with other stems with this shape, with both vowels, whereas the Tamim dropped the second vowel in all of these cases. The readers usually agree on the archaic Hijazi pattern, but occasionally a lexical item has the Tamim form.

While al-Farrā? does not comment on every single $\mathrm{CuCuC}$ noun present in the Quran, he mentions a fair number of them explicitly as being a Hijazi practice. Of the nouns mentioned by al-Farrā? (Lug $\bar{a} t$ ) that show disagreement among the readers we have huzu?an, kufu?an (pg. 26) qudus (pg. 44), qurubah (pg. 72) ğuruf (pg. 72), ?ukul (pg. 86), nukur (pg. 87). If we examine how the different readers treat these nouns, we find that not a single reader consistently opts for the Hijazi $(\mathrm{H})$ or Tamimi (T) form, although ?abū ĞaSfar comes fairly close to a regular treatment of the form as Hijazi (Ibn al-Ǧazarī, § 26692694): 


\begin{tabular}{|c|c|c|c|c|c|c|c|c|c|c|c|}
\hline & IK & $\mathbf{N}$ & $\mathrm{AJ}$ & IA & AA & $\mathrm{Y}$ & K & Ḥ & $X$ & $\check{S}$ & $H ̣^{14}$ \\
\hline$a l-q u d(u) s$ & $\mathrm{~T}$ & $\mathrm{H}$ & $\mathrm{H}$ & $\mathrm{H}$ & $\mathrm{H}$ & $\mathrm{H}$ & $\mathrm{H}$ & $\mathrm{H}$ & $\mathrm{H}$ & $\mathrm{H}$ & $\mathrm{H}$ \\
\hline ğur(u)f & $\mathrm{H}$ & $\mathrm{H}$ & $\mathrm{H}$ & $?^{15}$ & $\mathrm{H}$ & $\mathrm{H}$ & $\mathrm{H}$ & $\mathrm{T}$ & $\mathrm{T}$ & $\mathrm{T}$ & $\mathrm{H}$ \\
\hline$? u k(u) l$ & $\mathrm{~T}$ & $\mathrm{~T}$ & $\mathrm{H}$ & $\mathrm{H}$ & - & $\mathrm{H}$ & $\mathrm{H}$ & $\mathrm{H}$ & $\mathrm{H}$ & $\mathrm{H}$ & $\mathrm{H}$ \\
\hline$n u k(u) r$ & $\mathrm{~T}$ & $\mathrm{H}$ & $\mathrm{H}$ & $\mathrm{H}$ & $\mathrm{H}$ & $\mathrm{H}$ & $\mathrm{H}$ & $\mathrm{H}$ & $\mathrm{H}$ & $\mathrm{H}$ & $\mathrm{H}$ \\
\hline nuk(u)ran & $\mathrm{T}$ & $\mathrm{H}$ & $\mathrm{H}$ & $?^{16}$ & $\mathrm{~T}$ & $\mathrm{H}$ & $\mathrm{T}$ & $\mathrm{T}$ & $\mathrm{T}$ & $\mathrm{H}$ & $\mathrm{T}$ \\
\hline Sur(u)ban & $\mathrm{H}$ & $\mathrm{H}$ & $\mathrm{H}$ & $\mathrm{H}$ & $\mathrm{H}$ & $\mathrm{H}$ & $\mathrm{H}$ & $\mathrm{T}$ & $\mathrm{T}$ & $\mathrm{T}$ & $\mathrm{H}$ \\
\hline huz(u)?an & $\mathrm{H}$ & $\mathrm{H}$ & $\mathrm{H}$ & $\mathrm{H}$ & $\mathrm{H}$ & $\mathrm{H}$ & $\mathrm{H}$ & $\mathrm{T}$ & $\mathrm{T}$ & $\mathrm{H}$ & $\mathrm{H}+$ \\
\hline kuf(u)?an & $\mathrm{H}$ & $\mathrm{H}$ & $\mathrm{H}$ & $\mathrm{H}$ & $\mathrm{H}$ & $\mathrm{T}$ & $\mathrm{H}$ & $\mathrm{T}$ & $\mathrm{T}$ & $\mathrm{H}$ & $\mathrm{H}+$ \\
\hline al-yus $(u) r$ & $\mathrm{~T}$ & $\mathrm{~T}$ & $\mathrm{H}$ & $\mathrm{T}$ & $\mathrm{T}$ & $\mathrm{T}$ & $\mathrm{T}$ & $\mathrm{T}$ & $\mathrm{T}$ & $\mathrm{T}$ & $\mathrm{T}$ \\
\hline yus(u)ran & $\mathrm{T}$ & $\mathrm{T}$ & $\mathrm{H}$ ? & $\mathrm{T}$ & $\mathrm{T}$ & $\mathrm{T}$ & $\mathrm{T}$ & $\mathrm{T}$ & $\mathrm{T}$ & $\mathrm{T}$ & $\mathrm{T}$ \\
\hline$y u s(u) r \bar{a}$ & $\mathrm{~T}$ & $\mathrm{~T}$ & $\mathrm{H}$ & $\mathrm{T}$ & $\mathrm{T}$ & $\mathrm{T}$ & $\mathrm{T}$ & $\mathrm{T}$ & $\mathrm{T}$ & $\mathrm{T}$ & $\mathrm{T}$ \\
\hline al-ruS(u)b/ruS(u)ban & $\mathrm{T}$ & $\mathrm{T}$ & $\mathrm{H}$ & $\mathrm{H}$ & $\mathrm{T}$ & $\mathrm{H}$ & $\mathrm{H}$ & $\mathrm{T}$ & $\mathrm{T}$ & $\mathrm{T}$ & $\mathrm{T}$ \\
\hline$a l-\{u s(u) r$ & $\mathrm{T}$ & $\mathrm{T}$ & $\mathrm{H}$ & $\mathrm{T}$ & $\mathrm{T}$ & $\mathrm{T}$ & $\mathrm{T}$ & $\mathrm{T}$ & $\mathrm{T}$ & $\mathrm{T}$ & $\mathrm{T}$ \\
\hline Sus $(u) r a h$ & $\mathrm{~T}$ & $\mathrm{~T}$ & $\mathrm{H}$ & $\mathrm{T}$ & $\mathrm{T}$ & $\mathrm{T}$ & $\mathrm{T}$ & $\mathrm{T}$ & $\mathrm{T}$ & $\mathrm{T}$ & $\mathrm{T}$ \\
\hline $\operatorname{Sus}(u) r \bar{a}$ & $\mathrm{~T}$ & $\mathrm{~T}$ & $\mathrm{H}$ & $\mathrm{T}$ & $\mathrm{T}$ & $\mathrm{T}$ & $\mathrm{T}$ & $\mathrm{T}$ & $\mathrm{T}$ & $\mathrm{T}$ & $\mathrm{T}$ \\
\hline$a l-\operatorname{suh}(u) t$ & $\mathrm{H}$ & $\mathrm{T}$ & $\mathrm{H}$ & $\mathrm{T}$ & $\mathrm{H}$ & $\mathrm{H}$ & $\mathrm{H}$ & $\mathrm{T}$ & $\mathrm{T}$ & $\mathrm{T}$ & $\mathrm{T}$ \\
\hline$(a l-) ? u \underline{d}(u) n$ & $\mathrm{H}$ & $\mathrm{T}$ & $\mathrm{H}$ & $\mathrm{H}$ & $\mathrm{H}$ & $\mathrm{H}$ & $\mathrm{H}$ & $\mathrm{H}$ & $\mathrm{H}$ & $\mathrm{H}$ & $\mathrm{H}$ \\
\hline qur(u)bah & $\mathrm{H}$ & $\mathrm{T} ?$ & $\mathrm{H}$ & $\mathrm{H}$ & $\mathrm{H}$ & $\mathrm{H}$ & $\mathrm{H}$ & $\mathrm{H}$ & $\mathrm{H}$ & $\mathrm{H}$ & $\mathrm{H}$ \\
\hline Suq $(u)$ ban & $\mathrm{H}$ & $\mathrm{H}$ & $\mathrm{H}$ & $\mathrm{H}$ & $\mathrm{H}$ & $\mathrm{H}$ & $\mathrm{H}$ & $\mathrm{T}$ & $\mathrm{T}$ & $\mathrm{T}$ & $\mathrm{T}$ \\
\hline ruḥ(u)man & $\mathrm{T}$ & $\mathrm{T}$ & $\mathrm{H}$ & $\mathrm{H}$ & $\mathrm{T}$ & $\mathrm{H}$ & $\mathrm{T}$ & $\mathrm{T}$ & $\mathrm{T}$ & $\mathrm{T}$ & $\mathrm{T}$ \\
\hline$x u \check{s}(u) b$ & $\mathrm{H}$ & $\mathrm{H}$ & $\mathrm{H}$ & $\mathrm{H}$ & $\mathrm{T}$ & $\mathrm{H}$ & $\mathrm{T}$ & $\mathrm{H}$ & $\mathrm{H}$ & $\mathrm{H}$ & $\mathrm{H}$ \\
\hline fa-suḥ(u)qan & $\mathrm{T}$ & $\mathrm{T}$ & $\mathrm{H}$ ? & $\mathrm{T}$ & $\mathrm{T}$ & $\mathrm{T}$ & $\mathrm{H}$ ? & $\mathrm{T}$ & $\mathrm{T}$ & $\mathrm{T}$ & $\mathrm{T}$ \\
\hline tul(u)tay & $\mathrm{H}$ & $\mathrm{H}$ & $\mathrm{H}$ & $\mathrm{T} ?$ & $\mathrm{H}$ & $\mathrm{H}$ & $\mathrm{H}$ & $\mathrm{H}$ & $\mathrm{H}$ & $\mathrm{H}$ & $\mathrm{H}$ \\
\hline ğuz(u)?un, ğuz(u)?an & $\mathrm{T}$ & $\mathrm{T}$ & $\mathrm{T}$ & $\mathrm{T}$ & $\mathrm{T}$ & $\mathrm{T}$ & $\mathrm{T}$ & $\mathrm{T}$ & $\mathrm{T}$ & $\mathrm{H}$ & $\mathrm{T}$ \\
\hline šug $(u) l$ & $\mathrm{~T}$ & $\mathrm{~T}$ & $\mathrm{H}$ & $\mathrm{H}$ & $\mathrm{T}$ & $\mathrm{H}$ & $\mathrm{H}$ & $\mathrm{H}$ & $\mathrm{H}$ & $\mathrm{H}$ & $\mathrm{H}$ \\
\hline Sud $(u) r a n$ & $\mathrm{H}$ & $\mathrm{H}$ & $\mathrm{H}$ & $\mathrm{H}$ & $\mathrm{H}$ & $\mathrm{T} ?$ & $\mathrm{H}$ & $\mathrm{H}$ & $\mathrm{H}$ & $\mathrm{H}$ & $\mathrm{H}$ \\
\hline nud $(u) r a n$ & $\mathrm{H}$ & $\mathrm{H}$ & $\mathrm{H}$ & $\mathrm{H}$ & $\mathrm{T}$ & $\mathrm{H}$ & $\mathrm{T}$ & $\mathrm{T}$ & $\mathrm{T}$ & $\mathrm{H}$ & $\mathrm{T}$ \\
\hline $\operatorname{Sum}(u) r i-h \bar{\imath}$ & $\mathrm{H}$ & $\mathrm{H}$ & $\mathrm{H}$ & $\mathrm{H}$ & $\mathrm{T} ?^{17}$ & $\mathrm{H}$ & $\mathrm{H}$ & $\mathrm{H}$ & $\mathrm{H}$ & $\mathrm{H}$ & $\mathrm{H}$ \\
\hline ğub(u)lan & $\mathrm{H}$ & & & & $\mathrm{T}$ & $\mathrm{H}$ & $\mathrm{H}$ & $\mathrm{H}$ & $\mathrm{H}$ & & \\
\hline
\end{tabular}

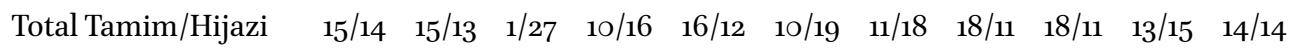


Besides these words there are three more words that have undergone a syn-

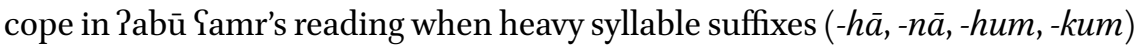
follow: ?ukul 'food', rusul 'messengers' and subul 'paths', yielding forms such as

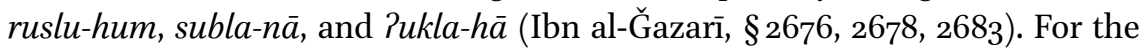
nouns of the shape $\mathrm{CuCuC}$ in his reading, the syncope conditioned by heavy syllable suffixes is almost regular. Only nuzulu-hum is normally not included in this syncope (although there are non-canonical transmissions that include it, see Ibn Muğāhid, 623).

From the words disagreed upon no clear pattern emerges. Most readers apply the Tamīmī syncope with some frequency (with the exception of Pabu Ğaffar), with some of the eastern readers being less prolific than some Hijazi readers in applying it and vice versa. However, many of the remaining wordsquite a few of which are explicitly mentioned by al-Farrā? as undergoing this development in Tamìmī-unanimously have the Hijazi form among all the readers, e.g. kutub 'books' (pg. 31), ${ }^{18}$ nusuk 'sacrifice' (pg. 33), nuzul 'hospitality' (pg. 53), sudus '1/1/6' (pg. 54), tulut '1/1/3' (pg. 54), qubul 'front' (pg. 77), dubur 'back' (pg. 77), \{unuq 'neck' (pg. 80), ğuruz 'barren' (pg. 85), \{umur 'life' (pg. 99). Besides this there are words in the Quran that have the right word shape to undergo syncope but are not explicitly mentioned by al-Farrā?, these too are consistently unsyncopated, e.g. zubur 'psalms', rubu ' '1/4, tumun '1/8', ğunub 'a distance', hurum 'in consecrated state', nușub 'idol', zufur 'nail', xumus '1/5', furut 'something excessive', huqub 'long period of time', șuhuf 'leaves', xumur 'veils', hulum 'dream; (+ balaga 'attain puberty')', xuluq 'disposition, nature', suquf 'roofs', hubuk 'celestial paths, orbits', dusur 'nails', and sufur 'insanity'. Every single reading therefore overwhelmingly adheres to the Hijazi forms, but the reasons why readers occasionally switch to the Tamimi form are unclear and unpredictable and cannot be obviously understood as an intrusion of the local dialect of the readers into their otherwise overall Hijazi reading.

\subsubsection{CuCuCāt Plurals of CuCCah Nouns}

Syncope also happens in the plural formation of short vowels of CuCCah nouns. According to al-Farrā? (Lug $\bar{a} t, 16)$, the people of the Hijaz and the Pasad form their plurals of zulmah, huğrah, gurfah and xuțwah with the infixation of $u$ before the last root consonant, before adding the regular feminine plural $-\bar{a} t$,

Ibn Muğāhid (534) transmits a single case of Tamīmī syncope of this noun in Q35:11 through two non-canonical transmitters of ?abū Yamr.

18 Vocalized Quranic manuscripts show that syncopated plurals may have been more common, e.g. ar-rusla (Q38:14) is found in Wolfen. Cod. Guelf. 12.11 Aug. $2^{\circ}, 5 \mathrm{v}$, l. 4.; Arabe 334d, 58r, l. 6; Arabe 347b, 81v, l. 2. 
i.e. zulumāt, ḩuğurāt, ġurufāt, xuțuwāt (also ḥurumāt, qurubāt). The Tamīm and some of the Qays are said to have not had this infixed vowel, i.e. $z u l m a \bar{t}$, huğrāt, gurfāt, xuțwāt.

In the Hijazi/Rasad Arabic reported by al-Farrā? the infixed vowel is always $u$, but historically this probably derived from an infixed ${ }^{*} a$ (see Suchard and Groen 2021). Traces of forms with the original $a$-infix are attested in the reading of the Medinan Pabū ĞaSfar who reads al-huğarāt (Q49:4) rather than al-h̆ğurāt as it is read by the other readers (Ibn al-Ğazarī, § 4247). Al-Farrā? (Luġăt, 132) explicitly mentions Pabū ĞaSfar's reading as an option besides huğurāt and huğrāat (Luġāt, 16). Despite ?abū ĞaYfar's archaic retention of the unharmonized plural CuCaCāt in this case, all the other plurals of this type just follow the reported Hijazi/Rasad form.

Al-xuțuwāt (Q2:168 etc.) is read in the Tamimi/Qaysi manner al-xutwāt by the NāfiY, al-Bazzī Yan Ibn Kațīr, Pabū Yamr and ŠuYbah Yan Yāșim, Ḥamzah and Xalaf. The other readers have the Hijazi/Asadi form (Ibn al-Ğazarī, § 2673). In all other cases the readers are in agreement in following the Hijazi/Rasad form. Here once again we see that the syncope is not applied regularly.

\subsubsection{FaSi/ul(ah) Nouns}

Al-Farrā? (Lugāt, 29) explicitly states that the people of Najd, who syncopated huwa and hiya after wa-, fa- and la-, also syncopate harim > harm rağul > rağl. Later, al-Farrā? (Luġāt, 39) reports that the Tamìm and Bakr b. Wā?il syncopate the vowel of original fasil and faSilah nouns, while the Hijaz and Pasad retain the original vowel. Thus, one gets kalmah instead of kalimah in the east. He also reports that 'others' say kilmah, with vowel harmony of the first vowel to the syncopated following vowel.

Most words of the shape $\mathrm{CaCiC}$ are unanimously read in the Hijazi way without syncope. Thus Saqib, malik, kalim, laSib, xadir, nakid (when not read as nakad), șaSiq, farih, farim and Sașir. There are two exceptions, where some of the readers stick to the Tamimi form. The first of these is rağili-ka (Q17:64) which is read as rağli-ka by everyone but Ḥafṣ (Ibn al-Ğazarī, § 3471). Considering the striking consensus (with the exception of Hafș), one may wonder whether we are not simply dealing with different lexical items, where most readers understood this word as a verbal noun rağl 'going by foot', and Hafș understood it as an adjective. The other case is bi-wariqi-kum (Q18:19), explicitly discussed by al-Farrā? (Luḡät, 85), which is read as bi-warqi-kum by Pabū Samr, Šưbah Yan Yāṣim, Ḥamzah, Rawḥ Yan YaYqūb and Xalaf (Ibn al-Ǧazarī, $\S 3492)$.

The Eastern syncopated form is not attested in the canonical readings for the feminine nouns of the shape of CaCiCah. There is complete consensus on the 
full vocalization of kalimah 'word,'19 nazirah 'postponement', naxirah 'decayed' (when not read as nāxirah, Ibn al-Ğazarī, § 45०8), wağilah 'afraid'. This syncope only occurs once in the plural form, namely nahisāt 'unlucky', which is read by Ibn Kat̄īr, Nāfí, ?abū Yamr and YaYqūb as nậsāt (Ibn al-Ǧazarī, § 4120).

As with fasil( $a h)$, nouns with the original shape $f a$ ful $(a h)$ are also recorded with syncope of the second stem vowel for the eastern dialects. These contain much fewer lexical items, and there is consensus on the Hijazi form among the canonical readers. The lexical items present in the Quran are saduqah and matulah (Tamīm: șudqah, muțlah, al-Farrā? Lugiāt, 54), Sadud (in the Hijaz also Sadid, Tamīm: Saḍd, Rabīiah Suḍd, al-Farrā? Luġāt, 85). The fourth of these nouns is rağul. While al-Farrā? (Luġāt, 36) explicitly assigns the form rağul to the Hijaz, the Tamīmì form is not mentioned specifically, and he simply mentions alternative singular formations such as rāğil and rağil. Sībawayh (IV, 113) explicitly assigns the expected form rağl to Bakr b. Wā?il and many people of the Banū Tamīm.

\subsubsection{CaCi/uCa Verbs}

As we have seen so far, some reading traditions irregularly undergo the Najdi syncope of nouns in only some lexical items. The grammarians also report the syncope of $i$ and $u$ in open syllables for verbs of the shape $\mathrm{CaCiCa}$ and $\mathrm{CaCuCa}$. Sībawayh explicitly cites Salima $>$ Salma, Silma and šahida $>$ šihda.

Among the canonical readers, there is consensus on the Hijazi forms of these verbs, except for two lexical items, namely, ni $m a$ 'how good an X' and bi?sa 'how bad an X', both of which are transparently from the verbs "naSima and *barisa respectively. ${ }^{20}$ For these there is complete consensus on the Tamim forms. A trace of the original Hijazi form of the verb can be found in the reading of نعمich is read as naSim-mā by Ibn Yāmir, al-Kisā?ī, Hamzah and Xalaf (Ibn al-Ğazarī, § 28o6). Indeed, al-Farrā? (Luġāt, 41) reports that naYim-mā is the practice of the people of the Hijaz. The other readers are either niSim-mā, $n i \zeta(\breve{l}) m-m \bar{a}$ or nißmmāa (all ultimately < * na Sima $m \bar{a})$. Al-Farrā? attributes niSim$m \bar{a}$ to Qays and Tamīm, whereas Sïbawayh (IV, 439f.) says "some of them say in recitation" niSim-mā. He argues that the form niSim-mā belongs to the dialect of those who say niSima rather than nißma, and reports that Pabū al-Xațāāb reports

19 Kilmah occurs on BnF Arabe 342a, 6r, l. 3 as a secondary reading, suggesting syncopated forms of these kind may have been more widespread, but nevertheless this reading is quite rare also in the manuscript evidence.

20 Traces of the verbal origins can still be gleaned from the fact that these verbs can agree in gender with their subject (although this is optional) in Classical Arabic, e.g. ni ma/niSmati l-mar?atu 'what a perfect woman!' (Fischer 2002, § 259.1). 
this as the dialect of Hudayl who also say liSibun rather than laSibun. Here is a clear admission that to Sībawayh readings that used both these forms were linguistically mixed.

In all other positions, the canonical readers all read nifma and bi?sa in their Tamimi forms. This distribution is surprising, but seems to reflect a trend that continues in Classical Arabic where words of 'emphatic qualification' (all transparently originally stative verbs) generally have both unsyncopated and syncopated forms. ${ }^{21}$ Fischer (2002, §259-263), in his discussion of these verbs, for example cites hasuna, husna, hasna 'how beautiful, magnificent', Sazuma, Suzma, \{azma 'how powerful, mighty', saruৎa, saria, suria 'how swift!'22 What the exact motivations are for preferring (or at least allowing) the Tamìmī forms in these constructions, whereas otherwise it is strictly avoided in the Quranic readings and the later Classical Arabic norm is difficult to reconstruct. But it seems likely that the grammarians felt they had a license to use these forms, because they were no longer felt to be verbs.

Sībawayh (IV, 115) goes further in his description, showing that any sequence of $\mathrm{CaCiC}$ is said to have been syncopated. Thus, he also reports that muntafixan would become muntafxan for example, and the imperative ințaliq would become intalq $(a)$. This is absent in the reading traditions, which consistently opt for the unsyncopated forms typical of the Hijaz.

\subsubsection{Conclusion}

While the syncopation of $i$, $u$ when such words follow a short syllable seems to be a regular process in the Najdi Arabic, the application of the rule is highly erratic in all of the canonical readers. This is not at all something that we would expect if the reading traditions were the outcome of natural language change. Likewise, we do not find that the region where different readers were active is a particularly good predictor of whether they will undergo syncope. The table summarizes the treatment of the six syncope categories discussed among the readers, where $\mathrm{N}$ stands for Najdi, $\mathrm{H}$ for Hijazi. For some of these the distribution is not absolute. In such $\mathrm{N}$ is given followed by the number of words that are

\footnotetext{
21 Nöldeke, however, astutely points out that especially in early prose it is difficult to know whether people would have pronounced these as the syncopated $b i$ is $a$ and ni\&ma rather than ba?isa and naSima. In poetry the norm seems to be the syncopated for, but Nöldeke cites a verse of Țarafah where metrically it is certainly trisyllabic (Nöldeke 1910, 217). 'how evil' and țāla 'how often', or are the result of syncope of geminated roots, a syncope that is attested in all forms of Arabic, e.g. Sazza, hadda 'how mighty', ğalla 'how great!' šadda 'how much', qalla 'how rare'.
} 
read in the Najdi manner. When $\mathrm{H} / \mathrm{N}$ is given it means that there is disagreement among the two canonical transmitters.

\begin{tabular}{|c|c|c|c|c|c|c|c|c|c|c|c|c|}
\hline & & IK & $\mathrm{N}$ & AJ & IA & AA & $\mathrm{Y}$ & $\mathrm{K}$ & Ḥ & $\mathrm{X}$ & Š & Ḥṣ \\
\hline 1. & $w a-h u w a \rightarrow w a-h w a$ & $\mathrm{H}$ & $\mathrm{H} / \mathrm{N}$ & $\mathrm{N}$ & $\mathrm{H}$ & $\mathrm{N}$ & $\mathrm{H}$ & $\mathrm{N}$ & $\mathrm{H}$ & $\mathrm{H}$ & $\mathrm{H}$ & $\mathrm{H}$ \\
\hline 2. & wa-li-yafial $\rightarrow$ wa-l-yafial & \multicolumn{11}{|c|}{ Consensus on the Najdi form } \\
\hline 3. & $\mathrm{CuCuC} \rightarrow \mathrm{CuCC}$ & $\mathrm{N} 15$ & $\mathrm{~N}_{15}$ & N1 & N1O & $\mathrm{N} 16$ & Nio & N11 & $\mathrm{N} 18$ & N18 & N13 & N14 \\
\hline 4. & CuCuCāt $\rightarrow$ CuCCāt & $\mathrm{H} / \mathrm{N}_{1}$ & N1 & $\mathrm{H}$ & $\mathrm{H}$ & $\mathrm{N}_{1}$ & $\mathrm{H}$ & $\mathrm{H}$ & N1 & $\mathrm{N}_{1}$ & N1 & $\mathrm{H}$ \\
\hline 5 a. & $\mathrm{CaCiC} \rightarrow \mathrm{CaCC}$ & $\mathrm{H}$ & $\mathrm{H}$ & $\mathrm{H}$ & $\mathrm{H}$ & $\mathrm{N}_{1}$ & $\mathrm{H} / \mathrm{N}$ & $\mathrm{H}$ & $\mathrm{N}_{1}$ & $\mathrm{~N}_{1}$ & $\mathrm{~N}_{1}$ & $\mathrm{H}$ \\
\hline $5^{b}$. & $\mathrm{CaCiCah} \rightarrow \mathrm{CaCCah}$ & \multicolumn{11}{|c|}{ Consensus on the Hijazi form } \\
\hline $5 \mathrm{c}$. & $\mathrm{CaCuC}(\mathrm{ah}) \rightarrow \mathrm{CaCC}(\mathrm{ah})$ & \multicolumn{11}{|c|}{ Consensus on the Hijazi form } \\
\hline 6. & $\mathrm{CaCi} / \mathrm{uCa} \rightarrow \mathrm{CaCCa}$ & \multicolumn{11}{|c|}{$\begin{array}{c}\text { Consensus on the Najdi form in: ba?isa } \rightarrow \text { bi?sa and nafima } \rightarrow \text { niFma } \\
\text { Otherwise: Consensus on the Hijazi form }\end{array}$} \\
\hline
\end{tabular}

\subsubsection{Additional Phonemic Long Vowels}

Several of the Quranic readings have more than three phonemic long vowels $(\bar{a}, \bar{l}, \bar{u})$. The categories of additional vowels described by the grammarians have already been discussed in section $\S \mathbf{2 . 2 . 2}$ and here we will examine how these forms are distributed across the readers.

\subsubsection{Hollow Root Passives}

As we saw in section $\S 2.2 .2 .5$, the Arab grammarians report three different vocalic options for the passives of hollow roots, which according to al-Farrā? can be attributed to the following tribes:

1. People of the Hijaz (Qurayš and those that neighbor them): $x \bar{\imath} f a / x i f n \bar{a}$, bìia/bißnā, qüla/qilnā.

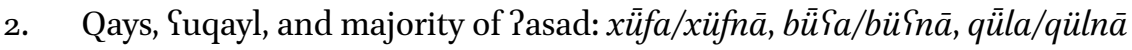

3. Banū Faq Yas and Banū Dubayr branches of Pasad: $x \bar{u} f a / x u f n \bar{a}, b \bar{u} \uparrow a / b u \uparrow$ $n \bar{a}, q u \bar{u} l a / q u l n \bar{a}$.

Ibn al-Ǧazarī ( $\$ 2629)$ reports that al-KisāPī, ${ }^{23}$ Hišām Yan ibn Yāmir, Ruways San YaYqūb all read in the manner of Qays, Suqayl and Pasad for all the verbs

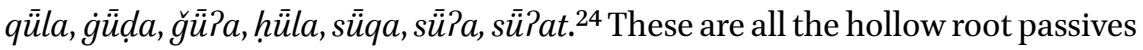

23 Al-Farrā? (Luḡàt, 14) also explicitly mentions that al-Kisā?ī reads it as such and that many of the readers followed him in it.

24 Rabin (Chaim Rabin 1951, 159) puzzlingly states that "the Kufan Kisā̄ì, however, read in each case $\ddot{u}[\ldots]$. Apparently the Classical language adopted the forms with $\ddot{u}$, but with the Hijazi spelling." It is difficult to understand what Rabin means by this, but the underlying assumption seems to be that "Classical Arabic" - the Arabic as considered normatively 
present in the Quran. More mixed is the treatment of this class by other read-

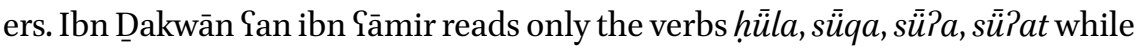
the other verbs that are expected to undergo this development are read with the Hijazi $\bar{\iota}$ vowel. Likewise, Nāif and Pabū Ğaffar only read sūं?a, sü̃?at and read the rest with $\bar{l}$. All other canonical readers consistently follow the Hijazi practice.

\subsubsection{Hollow Root Pimālah}

Hollow root Pimālah as found in hollow verbs that have an $i$ vowel with consonant initial suffix forms (e.g. teeba/țibtu), as discussed in section §2.2.2.3, is attributed to Tamīm, Pasad and Qays by al-Farrā? (Lugiāt, 17) and to some people of the Hijaz according to Sibawayh (IV, 120). Among the canonical readers, only Hamzah has this type of Pimālah quite regularly. He applies it to zēda 'to increase', šêra 'to want', ğêra 'to come', $x \bar{e} b a$ 'to fail', rēna 'to seize', $x \bar{e} f a$ 'to fear', $z \bar{e} \dot{g} a$ 'to wander', țêba 'to be good', dèqa 'to taste' and hệqa 'to surround', and any other form of these verbs where the long vowel is retained, such as zeedahum and $\breve{g} \bar{e} P \bar{u}$ (Ibn al-Ğazarī, § 2063). While he is fairly consistent in this regard, Hamzah fails to apply this ?imālah to māta he died,', ${ }^{25} \mathrm{ka} l \bar{u}-h u m$ 'they measured them' (Q83:3; kiltum Q17:35), zālat '(did not) cease' (Q21:15; ziltum Q40:34). He also makes an exception for $z \bar{a} \dot{g} a t\left(\mathrm{Q}_{33}: 10 ; \mathrm{Q}_{3} 8: 63\right)$ although other forms of this verb do undergo Pimālah. ${ }^{26}$

So even within Hamzah's reading, which is the closest to the regular application of this type of Pimālah, this sound change has irregular lexical exceptions. The other readers are less regular in its application. Ibn Dakwān and Xalaf only applied Pimālah for forms of the verb šêr?a 'he wanted' and ğ $\bar{e} \bar{e} ? a$ 'he came', and Ibn Dakwān adds to this zeeda 'he increased'. All transmissions agree that he applied it to fa-zéda-hum (Q2:10), but the others are a cause for disagreement among his transmitters. There is also disagreement as to whether Ibn Dakwān reads $x \bar{e} b a$ 'to fail' (Ibn al-Ǧazarī, § 2064-2065). For the other transmitter of Ibn

acceptable by the Arab grammarians - could only have one of these forms, rather than all three. It is difficult to reconstruct what caused Rabin to conclude that "the Classical language" had $\bar{u}$ and only $\bar{u}$. It seems to stem from the fact that al-Kisā?ī read it as such, apparently assuming that this Quranic reader and grammarian could not have recited in any other language but the "Classical language". But if this is what Rabin meant, I do not understand what he would make of the majority of readers that read with $\bar{\imath}$ instead.

25 Hamzah consistently has an $i$ vowel in the short stem, which means it would require Pimālah according to the grammarians, ibn al-Ğazarī ( $(2881)$.

26 Ibn al-Ğazarī adds that ibn Mihrān transmits in the transmission of Xallād that zēgat does undergo Pimālah. 
Yāmir, Hišām, there is disagreement whether the words šểa, $\breve{g} \bar{e} ? a$, zeêda and $x \bar{e} b a$ are to be read with Pimālah (Ibn al-Ǧazarī, § 2066). Finally, al-Kisā?ì, Xalaf and ŠuSbah read rēna (Ibn al-Ğazarī, § 2067). From this overview it should be clear that not a single one of the readers consistently follows a regular dialectal distribution for this development.

\subsubsection{Phonemic Ē on III-y Nouns and Verbs}

As discussed in section $\S$ 2.2.2.2, some forms of Arabic made a distinction between the Palif maqșūrah written with ?alif and with $y \bar{a}$ ?. Those written with $y \bar{a}$ ? , being mostly III-y roots, derived forms and the feminine ending such as in huble 'pregnant' have a phonemic vowel -ē. According to al-Farrā? (Lugiàt, 21) the people of the Najd had ramē 'to throw', qadè 'to conclude, decree' etc. whereas the people of the Hijaz had ramā, qad̄a etc. for III-y verbs, while both have $-\bar{a}$ for III- $w$ verbs. Al-Kisā?ī and Hamzah are well-known for having this phonemic distinction (Ibn al-Ğazarī §1968). Warš Yan Nāfi (along the most popular transmissions in the path of al-?azraq) likewise retains this distinction but has a lower realization $\bar{a}$ (Ibn al-Ğazarī § 2023). ${ }^{27}$ These three can therefore be seen as having a fairly regular reflex of this development.

Other readers apply Pimālah only sporadically: Ḥafṣ fan Yāșim reads it only once in mağrē-hā (Q11:41, Ibn al-Ğazarī, §1992). ŠuYbah San Yāșim reads it for re?ēe 'he saw' (Ibn al-Ǧazarī, § 2004), ${ }^{28}$ ramē 'he threw' (Ibn al-Ǧazarī, § 1996) whenever they occur, and $3 a\{m \bar{e}$ 'blind' in its two attestations in Q17:72, and not in any of its 12 other attestations (Ibn al-Ğazarī, §1998). ?abū Yamr has a special, and rather artificial treatment which will be discussed in more detail in § 3.6.6.1 below. This highly lexically specified application of the III-y ?imälah is unlikely to be the result of natural language change.

\subsubsection{Lexically Determined i-umlaut Timālah}

The Arab grammarians recognize multiple types of Pimālah, two of these we have discussed already and must essentially be thought of as representing a phonemic distinction between $\bar{e}$ and $\bar{a}$. However, the type of the Pimālah that takes up the largest amount of Sibawayh's discussion is best thought of as a form of $i$-umlaut where any $\bar{a}$ that is adjacent to an $i$ or $\bar{l}$ is raised to $\bar{e}$, unless it is directly adjacent to one of the emphatic $(s, d, t, z)$ or uvular consonants $(q, \dot{g}, x)$ or if any of these consonants occur later in the word. This conditioning is well-

\footnotetext{
27 Ibn Muğāhid (145) reports $\bar{a}$ for both Warš and Qālūn. Ibn al-Ǧazarī reports the reading of Qālūn from a different transmitter.

28 N.B. also with Pimālah of the first syllable.
} 
known and quite similar to several modern Arabic dialects. ${ }^{29}$ While this type of Pimālah is frequently attributed by modern scholars to the tribes of Najd, or more specifically Tamim, Sībawayh's comprehensive description does not explicitly attributed it to any eastern tribe, only mentioning that that the people of the Hijaz never apply Pimālah in such cases. Al-Farrā? is much less systematic in his description of this phenomenon, but more explicit in which tribes do apply it. He reports the people of the Hijaz back the vowel (yufaxximūna) of whereas the people of Najd among the Tamìm and Qays say al-kēfirūna (yuširūuna Pilā l-kāfi bi-l-kasr).

While the Pimālah of this type is clearly non-phonemic in Sībawayh's description, and mostly the result of a regular predictable historical process in the modern dialects that have it as well, oddly enough its occurrences in the Quranic reading traditions are highly lexically determined. The transmitters of Ibn Yāmir most frequently apply this type of $i$-umlaut Pimālah, but even for this reader it is entirely lexically determined and most of the nouns that would qualify following Sībawayh's description do not undergo it. Ibn al-Ğazarī ( $§ 2068-2083$ ) discusses these cases, and they have been summarized below.

Both Hišām and Ibn Dakwān (according to some transmission paths) apply the $i$-umlaut to one case of an unemphatic $\mathrm{CaCa} C i C$ plural, namely, mašeribu 'drinks' (Q36:73). However other words that qualify just as well for this shift, are not read in such a way, for example al-ğawärihi 'the predators' (Q5:4), alhanāğira 'the throats' (Q33:10), manāzila 'positions' (Q36:39), and even manäfi u 'benefits' which is the word that directly precedes mašêribu in Q36:73.

Hišām (according to some transmission paths) also applies $i$-umlaut to one CâCiCah noun, namely, Pēniyatin 'boiling' (Q88:5) while other nouns of the same shape, such as Pātiyah 'coming' (Q15:85; Q20:15; Q22:7; Q40:59) do not undergo it.

The noun Yēbidun and Yēbidūna undergo i-umlaut in Hišām's transmission (again according to some transmission paths) in Q109, 3, 4, 5 but not in any of its other attestations. So, without $i$-umlaut are รābidūna (Q2:138; Q23:47), alSābidūna (Q9:112), Sābidìna (Q21:53, 73, 106), li-l-Sābidìna (Q21:84); al-Sābidìna $\left(\mathrm{Q}_{43}: 81\right)$ and Iábidātin (Q66:5). As such, the $i$-umlaut of this word is not just lexically determined, but determined by position in the Quranic text. ${ }^{30}$ This is especially striking because another word that would have qualified in this

29 See Levin (1992) for a compelling discussion and compare the conditioning to Christian Baghdadi, for example Abu-Haidar (1991, 29f.).

3o Phonemic distinctions determined by the position in the text are a phenomenon also found in the reading tradition of the Hebrew Bible (Suchard 2018, 200). 
Surah, namely, al-käfirūna (Q109:1) does not undergo the Pimālah. One therefore cannot argue that Hišām is transmitting this single Sūrah in a different dialect that did undergo the Pimālah.

Similar irregularity can be seen for Ibn Yāmir's other transmitter Ibn Dakwān, who has an $i$-umlaut on some, but not all, nouns with the shape CiCCāC. He read al-mihrēb, and Simrēn, al-Pikrēm and Pikrēhi-hinna in its one attestation (Q24:33) (the latter three all in only some transmission paths) but other nouns are not affected, e.g. zilzälan (Q33:11), al-Pisläm (Q61:7), Piḩsānan (Q46:15). Finally, Ibn Dakwān (in some transmission paths) reads Pimālah in the words al-ḥawèriyyinna and li-š-šéribina.

Hamzah has an even more limited application, only using it in the phrase Pana Pêti-ka bi-hì $\left(\mathrm{Q}_{27} 7: 39,40\right)$ but for example not **Pêti-kum (Q28:29). Besides this he has $i$-umlaut in difêfan $\left(\mathrm{Q}_{4}: 9\right)$.

A final example is the $i$-umlaut in the pronunciation of (al-)kēfirina 'the disbelievers' by Pabū Yamr and al-Dūrî Yan al-Kisā?ī (NB not with the nominative (al-)kāfirūna, which would qualify in Sībawayh's definition). Warš also has his distinctive in-between ?imālah $(\bar{a})$ for this word only.

Sībawayh's system clearly represents a linguistic reality, and its linguistic reality is confirmed by the fact that it describes the system as found in many modern dialects quite accurately. This $i$-umlaut is attested among several different canonical readers. But nowhere does it form the regular, phonetically conditioned system in the way that Sibawayh describes it. This is unexpected if we take the Quranic readings as a reflection of a natural language.

\subsubsection{Dual Deictics}

Al-Farrā? (Lug àt, 94) reports a clear split of the deictic system between the Hijaz and Najd when it comes to the dual deictics. Qays and Tamim have hādāanni (proximal masculine), hātaynni (proximal feminine) and d̂ānnika (distal masculine). These same tribes also have alladāanni, alladaynni for the dual relative pronoun. The dialect of the Hijaz and Pasad have a -āni/-ayni in all these cases.

The Meccan Ibn Katīi has the Qays and Tamìm form for both the proximal and the distal: hādānni (Q20:63; Q22:19) hätaynni (Q28:27), fa-dānnika $\left(\mathrm{Q}_{28: 32)}\right.$ as well as the dual relative pronoun alladānni, alladaynni $\left(\mathrm{Q}_{4}: 16\right.$; Q41:29). The Basrans Pabū Yamr and YaYqūb follow Ibn Katīir in using the eastern form only for the distal demonstrative fa-d̄ānnika (Ibn al-Ğazarī § 2915). The other canonical readers, however, adhere to Hijazi and Pasad forms of the deictics and relative pronoun. 


\subsubsection{Dialectal Difference in Short Vowels}

3.3.6.1 $\quad \mathrm{Cu} / \mathrm{iCiyy}(\mathrm{ah})$

The Fưūl(ah) nouns for III- $y$ can either retain the initial $u$ as per the Hijazi practice, or they can have a harmonized $i$, as per the practice of ?asad and those who surround them (al-Farrā? Lug $\bar{a} t, 68) .{ }^{31}$ Once again we find that there is significant disagreement among the readers whether to follow the Hijazi or Pasadī practice, although for Sișiyy all readers agree on the ?asadī form (Ibn al-Ğazarī, $\S 3143, \S 3549$ ). Probably related to this development is the pronunciation of durriyyah as dirriyyah 'offspring' (al-Farrā? Luġăt, 39). In this case al-Farrā? is less specific and says the people of the Hijaz say durriyyah and 'other Arabs' say dirriyyah. But it seems safe to consider this part of the same development. There is consensus on the Hijazi pronunciation of this word.

The noun Q24:35 ذرى 'shining', read variously as durriyyun, dirri? rî̉un (Ibn al-Ğazarī § 3731) is plausibly explained as a nisbah derivation of durr 'pearls'. This yields more or less the same phonetic environment as the CuCiyy nouns discussed so far, and thus undergoes the same development. The wordfinal ? present among some of the readers is likely pseudocorrect (see §6.4.6). The Table below illustrates the forms and shows that not a single one of the readers shows a regular pattern, though the Hijazi pronunciation is most common, $\mathrm{H}=$ Hijazi, $\mathrm{A}=$ Asad, $+\mathrm{P}=$ the word has a stem-final ?.

\begin{tabular}{|c|c|c|c|c|c|c|c|c|c|c|c|}
\hline & IK & $\mathbf{N}$ & AJ & IA & AA & $\mathrm{Y}$ & K & $\ddot{H}$ & $\mathrm{X}$ & $\check{S}$ & Ḥṣ \\
\hline ǧutiyyan & $\mathrm{H}$ & $\mathrm{H}$ & $\mathrm{H}$ & $\mathrm{H}$ & $\mathrm{H}$ & $\mathrm{H}$ & A & A & $\mathrm{H}$ & $\mathrm{H}$ & A \\
\hline șuliyyan & $\mathrm{H}$ & $\mathrm{H}$ & $\mathrm{H}$ & $\mathrm{H}$ & $\mathrm{H}$ & $\mathrm{H}$ & A & A & $\mathrm{H}$ & $\mathrm{H}$ & A \\
\hline Sutiyyan & $\mathrm{H}$ & $\mathrm{H}$ & $\mathrm{H}$ & $\mathrm{H}$ & $\mathrm{H}$ & $\mathrm{H}$ & A & A & $\mathrm{H}$ & $\mathrm{H}$ & A \\
\hline bukiyyan & $\mathrm{H}$ & $\mathrm{H}$ & $\mathrm{H}$ & $\mathrm{H}$ & $\mathrm{H}$ & $\mathrm{H}$ & A & A & $\mathrm{H}$ & $\mathrm{H}$ & $\mathrm{H}$ \\
\hline huliyyi-him $(\bar{u})$ & $\mathrm{H}$ & $\mathrm{H}$ & $\mathrm{H}$ & $\mathrm{H}$ & $\mathrm{H}$ & -32 & $\mathrm{~A}$ & A & $\mathrm{H}$ & $\mathrm{H}$ & $\mathrm{H}$ \\
\hline Sișiyyv-hum $(\bar{u})$ & A & A & A & $\mathrm{A}$ & A & A & $\mathrm{A}$ & A & A & A & A \\
\hline durriyyah & $\mathrm{H}$ & $\mathrm{H}$ & $\mathrm{H}$ & $\mathrm{H}$ & $\mathrm{H}$ & $\mathrm{H}$ & $\mathrm{H}$ & $\mathrm{H}$ & $\mathrm{H}$ & $\mathrm{H}$ & $\mathrm{H}$ \\
\hline durriyyun & $\mathrm{H}$ & $\mathrm{H}$ & $\mathrm{H}$ & $\mathrm{H}$ & $A+?$ & $\mathrm{H}+?$ & $A+?$ & $\mathrm{H}+\mathrm{?}$ & $\mathrm{H}$ & $\mathrm{H}+\mathrm{?}$ & $\mathrm{H}$ \\
\hline
\end{tabular}

31 Presumably the vowel harmony of CuCyah nouns towards CiCyah is related to this phenomenon. This is reported by al-Farrā? (Luġāt, 64, 74). He attributed the xifyah pronunciation to Quḍāiah whereas miryah is attributed more broadly to the Hijaz, while muryah is considered the ?asad and Tamīm form. There is consensus among the readers on reading xufyah and miryah.

Yåqūb reads halyi-him instead. 


\subsubsection{CiCwān Nouns}

Al-Farrā? (Luġāt, 47, 62, 77) on multiple occasions reports that nouns that historically probably had the shape *CiCwān undergo harmony of the high vowel * $i$ to $u$ under influence of the following $w$ among the Qays and Tamim, while the vowel remains $i$ in the Hijaz. The four words explicitly discussed by al-Farrā? that show this dialectal distribution in the Quran are ridwān 'approval', Pixwān 'brothers', qinwān 'cluster of dates' and șinwān 'trees growing from a single root'.

For Pixwān, qinwān and șinwān there is complete consensus on the Hijazi form among the Quranic readers. For ridwān most readers read ridwān in all contexts, but ŠuSbah Yan Sāșim always reads ruḍwān with the exception of Q5:16, where he reads it as riḍwān (Ibn al-Ğazarī, § 2832).

Besides this, we must likely also include Sudwān, Sidwān 'enmity' in this discussion, which is recorded by the Arabic lexicographical tradition with both forms (Lisān, 2846b). There is consensus among the Quranic readings on the Qays/Tamīm form Sudwān.

\subsubsection{Mit- and Dim-}

Al-Farrā? (Lugāat, 49) tells us that the hollow verbs māta 'to die' and dāma 'to last' have a vowel $u$ in the short stem mutta and dumta among the people of the Hijaz, while the Tamim have mitta and dimta. From a comparative perspective, it is clear that for mäta at least, the form with an $* i$ vowel is original, having developed from an earlier *mawita (Suchard 2016; van Putten 2017a). This is less clear for $d \bar{a} m a$, but seems likely as well. The readers display a highly mixed treatment of these forms for māta where Hafș even uses both forms in specific locations in the Quran (Ibn al-Ğazarī, § 2881). There is, however, full consensus on the Hijazi form for the dāma. ${ }^{33}$

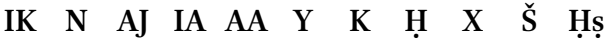

$\begin{array}{llllllllllll}\text { mittum Q3:157, 158 } & \mathrm{H} & \mathrm{T} & \mathrm{H} & \mathrm{H} & \mathrm{H} & \mathrm{H} & \mathrm{T} & \mathrm{T} & \mathrm{T} & \mathrm{H} & \mathrm{H} \\ \text { mittum Q23:35 } & \mathrm{H} & \mathrm{T} & \mathrm{H} & \mathrm{H} & \mathrm{H} & \mathrm{H} & \mathrm{T} & \mathrm{T} & \mathrm{T} & \mathrm{H} & \mathrm{T} \\ \text { mittu Q19:23; Q19:66 } & \mathrm{H} & \mathrm{T} & \mathrm{H} & \mathrm{H} & \mathrm{H} & \mathrm{H} & \mathrm{T} & \mathrm{T} & \mathrm{T} & \mathrm{H} & \mathrm{T} \\ \text { mitta Q21:34 } & \mathrm{H} & \mathrm{T} & \mathrm{H} & \mathrm{H} & \mathrm{H} & \mathrm{H} & \mathrm{T} & \mathrm{T} & \mathrm{T} & \mathrm{H} & \mathrm{T} \\ \text { mitna Q23:82; Q37:16, 53; Q50:3; Q56:47 } & \mathrm{H} & \mathrm{T} & \mathrm{H} & \mathrm{H} & \mathrm{H} & \mathrm{H} & \mathrm{T} & \mathrm{T} & \mathrm{T} & \mathrm{H} & \mathrm{T} \\ \text { dumta Q3:75 } & \mathrm{H} & \mathrm{H} & \mathrm{H} & \mathrm{H} & \mathrm{H} & \mathrm{H} & \mathrm{H} & \mathrm{H} & \mathrm{H} & \mathrm{H} & \mathrm{H}\end{array}$

33 Yaḥyā b. Wattāāb is attributed as reading Q3:75 dimta, Q5:96 dimtum (Ibn Xālawayh muxtașar, 21, 35). 
(cont.)

\begin{tabular}{lcccccccccccc}
\hline & IK & $\mathbf{N}$ & AJ & IA & AA & Y & K & H & X & $\check{S}$ & Hs ș \\
\hline dumtum Q5:96 & H & H & H & H & H & H & H & H & H & H & H \\
dumtu Q5:117, Q19:31 & H & H & H & H & H & H & H & H & H & H & H
\end{tabular}

\subsubsection{Disagreement in Pluralization}

The plural of Pasir 'prisoner' among the people of the Hijaz is $?$ ?usārā. The people of the Najd most commonly use ?asrā (Al-Farrā? Lug $\bar{a} t$, 29). Al-Farrā? goes on to say that the plural ?asrä "is the best of the two options in Arabic, because it has a similar pattern as ğarīh pl. ğarhāa and șarī̧ pl. șarৎā." This plural occurs three times in the Quran, and there is significant disagreement on which form is to be used, most readers in fact use both the Hijazi and the Najdi forms (Ibn al-Ğazarī, § 2708, 3192).

\begin{tabular}{llllllllllll}
\hline & IK & N & AJ & IA & AA & Y & H & X & K & S & Ḥ̣ \\
\hline Q2:85 & H & H & H & H & H & H & N & H & H & H & H \\
Q8:67 & N & N & H & N & N & N & N & N & N & N & N \\
Q8:7O & N & N & H & N & H & N & N & N & N & N & N \\
\hline
\end{tabular}

\subsubsection{Cu/ìüC Plurals}

There are some cases where we likewise find unexpected and mixed treatments even when the early grammarians whom we examine here do not explicitly attribute these forms to specific dialects. This is the case, for example, for the plurals of several CayC nouns like bayt 'house', gayb 'a hidden thing', fayn 'eye, well', ğayb 'bosom' and šayx 'elder' which show disagreement of the first vowel of the plural stem. Sibawayh (III, 589) describes these explicitly as having a $\mathrm{CuCu} C$ plural pattern and mentions no other options. He does mention that for diminutive we find šiyayx, siyayd and biyayt as options besides šuyayx, suyayd and buyayt, although he explicitly considers the form with $u$ better (Sïbawayh III, 481). Al-Farrā? (Luġa $\bar{t}, 5^{6}$ ) discuss three different options for the plurals: buyūt, biyūt and büyüt. He considers the last of these three to be the best and most common.

While Ibn Muḡāhid (178f.) reports ġuyūb, but biyūt, Siyūn, ğiyūb and šiyūx for al-Kisā?ī, one of the manuscripts used in the edition has an extra anony- 
mous attribution that reports the front rounded vowel $\ddot{u}$ for al-Kisā?ī (probably only those reported with $i$, but the wording is ambiguous). ${ }^{34}$ For Hamzah, he reports that he pronounces $i$ for all of these words, but that Xalaf and (the now non-canonical transmitter) Pabū Hišām $\leftarrow$ Sulaym $\leftarrow$ Hamzah read ğüyuubihinna. Ğüyübihinna is also reported for Yahyā b. Tādam $\leftarrow$ ŠuYbah $\leftarrow$ Yāṣim. Al-Dānī ( $\breve{a} m i \varsigma, 416 \mathrm{f}$.) brings many more transmissions with büyūt-type plurals, for all three Kufans. The forms with the front rounded vowel have been lost in the canonical transmissions as they are adhered to today (and reported on by al-Dānī taysīr and Ibn al-Ǧazarī), but it is clear that this was once quite popular in the Kufan tradition, which helps us understand al-Farrā?'s approving tone of this pronunciation.

The shift of "uy > $y$ is otherwise very irregular, something we would not expect if it had been the outcome of a regular sound shift. Warš Yan Nāfí, ?abū Samr and Ḥaf̣̦ Yan Yāṣim, Rabū Ğaffar and YaYqūb all regularly have CuyūC, whereas Hamzah (in the now-canonical transmission) regularly has CiyūC. The remaining readers all have a single exception to their general pattern, though which word constitutes the exception differs per reader (Ibn al-Ǧazarī, § 2755). Such behaviour is hard to explain as the outcome of the development of natural language and should rather be seen from the perspective of different readers consciously incorporating different dialectal forms into their readings, while not doing so in other places.

\begin{tabular}{|c|c|c|c|c|c|c|c|c|c|c|c|c|c|}
\hline & IK & $\mathbf{N}$ & & AJ & AA & $\mathrm{Y}$ & IA & & Ḥ & $X$ & $\mathrm{~K}$ & A & \\
\hline & & W & $\mathbf{Q}$ & & & & $\mathbf{H}$ & ID & & & & $\check{S}$ & Ḥs \\
\hline بيوت & biyūt & buyūt & biyūt & buyūt & buyūt & buyūt & biyūt & biyūt & biyūt & biyūt & biyūt & biyūt & buyūt \\
\hline غيوب & $\dot{g} u y \bar{u} b$ & $\dot{g} u y \bar{u} b$ & $\dot{g} u y \bar{u} b$ & $\dot{g} u y \bar{u} b$ & $\dot{g} u y u \bar{b} b$ & $\dot{g} u y \bar{u} b$ & $\dot{g} u y \bar{u} b$ & $\dot{g} u y \bar{u} b$ & $\dot{g} \iota y \bar{u} b$ & $\dot{g} u y u \bar{u} b$ & $\dot{g} u y \bar{u} b$ & $\dot{g} \dot{i} \bar{u} \bar{b}$ & $\dot{g} u y u ̄ b$ \\
\hline عيون & Siyūn & รuyūn & Suyūn & Suyūn & Suyūn & Suyūn & Suyūn & Sìyūn & Siyūn & Suyūn & Sìyūn & Siyūn & Suyūn \\
\hline جيو:هن & ǧìūb & ğuyūb & ğuyūb & ğuyūb & ğuyūb & ğuyūb & ğuyūb & ǧivūb & ǧìūb & ğuyūb & ǧìūb & ǧuyūb & ğuyūb \\
\hline شيوخا & šiyūx & šuyūx & Šuyūx & šuyūx & šuyūx & šuyūx & šuyūx & šiyux & šiyux & šuyūx & šiyūx & šiyūx & šuyūx \\
\hline
\end{tabular}

\subsubsection{The Readings Do Not Reflect Natural Language}

As should be clear from the discussion of the previous sections, all of the linguistic developments discussed above fail to apply consistently in the Quranic

34 Wa-ruwiya Sani l-kisāîiyyi ?annahū kāna yaqraßu hādihi l-ḥurūfa bi-Pišmāmi l-harfi l-Pawwali ḍ-dammi muxtalisan mițliqüla, wa güüda wa-mā ?ašbaha dālik. I am indebted to Nasser $(2020,225)$ for making me realize that these variants were reported by Ibn Muğāhid. 
reading traditions. This is rather surprising from the perspective of the descriptions of the grammarians, who clearly present these processes as regular rules, often stating explicitly things like 'those who say wa-l-yaffal also say wa-hwa'. The readings fail to reflect any regular relation of the sort presented by the grammarians. The lack of regular sound change clearly implies that the readings do not reflect any form of natural language.

Seemingly irregular outcomes of sound changes may be the result of borrowing between closely related languages (Hock 1991, $47 \mathrm{ff}$ ). While in principle, one could try to explain what we find in the readings in this manner, the sheer amount of dialect borrowing that would have to be assumed and the lack of clear patterns among the readers would be difficult to square with the data as presented by the grammarians. Alternatively, one might imagine we are looking at several sound changes in progress. As Labov (1994, Part D, pp. 419-543) shows, sound change can surface as irregular distributions of the sound change in ways that are not entirely predictable while the sound change is still in progress. One might imagine that some of the sound changes discussed above may be understood as part of this kind of distribution, fossilized in time as the reading traditions were transmitted with the utmost precision. However, the great amount of sound changes that would have to be considered to have been caught 'mid shift' by the Quranic reading traditions would be highly unusual, especially considering the fact that the Arab grammarians, active around the same period as the readers of these reading traditions give no indication whatsoever that these shifts were changes in progress, and rather point to regularly conditioned sound changes that can be clearly formulated, and by all intents and purposes seem complete in the different dialects they are attributed to.

Therefore, the chaotic situation that we see among the canonical readers must, in part, be the result of conscious incorporation of different linguistic forms into a single reading. The exact motivation for the haphazard incorporation of such features is not readily recoverable. It seems clear that some amount of regional influence plays a role in this regard. For example, it is unlikely to be a coincidence that three of the four Kufan readers all have regular phonemic $\bar{e}$ on III- $y$ stems ( $\$ 3.3 \cdot 3 \cdot 3)$, which strikes one as likely to be the result of the TeacherStudent relationships that Hamzah, al-Kisāî̀ and Xalaf have with one another. As Yāșim falls outside that cluster, only sharing a teacher several generations higher up, his deviation from the Kufan norm can be understood. ${ }^{35}$

35 For teacher student-relationships I have relied here on the description of al-Dānī (taysīr, 9-10). Other sources report slightly different details as to how Hamzah relates to alSulamī, reporting that he learned from Pabū ?ishāà, who studied directly under al-Sulamī, whereas, Yahyā b. Wattāāb did not learn from al-Sulamī (Ibn al-Ǧazarī § $75^{-1} 75^{2}$ ). 


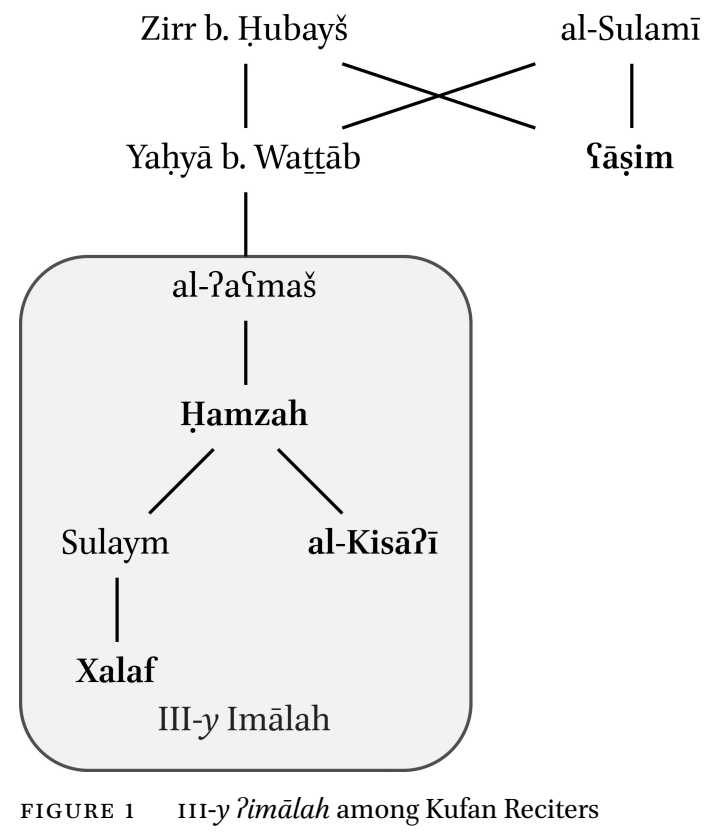

While teacher student relations can explain some amount of the variation, many of the disagreements are not easily explained in this manner. If we turn, for example, to the syncopation of $\mathrm{CuCuC}$ nouns ( $\$$ 3.3.2.3), we are confronted with a striking lack of agreement between the two Medinan readers Pabū ĞaSfar and NāfiS, while the latter is a direct student of the former. Likewise, the disagreements between nouns of this type between Ḥamzah, Xalaf and al-Kisā?ī are not easily explained in this manner. There is no straightforward explanation why Ḥamzah and Xalaf chose to read جرف (Q9:109) as ğurfin while al-Kisā?ī chose ğurufin, while with the word $\zeta^{\prime}$ (e.g. Q18:74) it is al-Kisā?ī and Ḥamzah that agree on the syncopated form nukran, whereas Xalaf opts for nukuran.

\subsection{The Readings Are Not Dialects}

It should be clear from the discussion in section $\S 3.3$ that there is a significant amount of linguistic variation present in the Quranic reading traditions. These linguistic differences between the readings are often explained today as being the result of regional pronunciations or dialects of Arabic. This is a view commonly espoused by Muslim scholars and laypeople alike, as it is believed that the prophet Muhammad taught his followers in their native dialect, sometimes claiming that the angel Gabriel revealed it to the prophet as such (As-Said 
1975, 53; al-Azami 2003, 62 f., 154f.). This is not a view that seems to have been endorsed in the early qirā? $\bar{a} t$ works, but that of course need not mean that this is incorrect.

The report is easily dismissed in its most literal interpretation, though. It is readily apparent that Hijazi readers do not employ Hijazi pronominal forms, for example. Likewise, a client of lasad (such as fāșim) does not exclusively use ?asadĩ forms. Of course, it need not be the case that a reader would be employing his own local dialect, but we find that none of the readers stick to regional forms with any consistency at all. For example, the widespread syncopation and vowel harmony associated with the eastern tribes only shows up erratically in the reading traditions with no obvious patterns discernable.

Especially in the general principles of the readings - widespread features that apply regularly to words whenever they occur-we do find some regional trends. Van Putten \& Sidky (forthcoming), for example, show that the use of long plural pronouns of the type ?antumū, humū, falay-himū etc. is typical for the Hijazi readers, not just the canonical Pabū ĞaSfar, Nāfiৎ (both Medina) and Ibn Katīr (Mecca), but also the non-canonical Meccan Ibn Muhayșin. Yet, the Arab grammarians are explicit in pointing out that this is not a regional dialectal feature, but an option for any speaker of Arabic of whatever tribe.

One could, of course, call into question the accuracy of the reports of the grammarians. Perhaps, for some reason, the reports about the dialectal features simply did not map onto reality in any way. It is difficult to envision a motivation for the grammarians to fabricate a vast and intricate system of dialectological data that was agreed upon by the otherwise rivalrous grammatical schools of Basra and Kufa. Moreover, the data they present often seems to show a clear and regular application of sound laws, which makes these developments look like natural linguistic data even though the concept of regular sound laws was not part of the framework of the grammarians, which makes such data look even more natural.

Had this data been fabricated, we would expect it to serve (and be employed for) theological or ideological purposes. It would, for example, have been quite advantageous for al-Farrâ? to claim that all the features that the readers have (or at least what his teacher al-Kisā?ī or the other Kufan readers read), were a perfect reflection of the dialect of the Qurays and therefore the most eloquent and authentic form of recitation, but this is not what he reports. Very often alFarrā? explicitly mentions the reading of the Kufan readers even when they are at odds with the dialectal forms of the Hijazis or Qurayš. An example of this is the presence of the vowel $\bar{u}$ in hollow root passives (\$3.3.3.1), which alFarrā? explicitly attributes to his teacher, al-Kisā?ī, while also explicitly calling it a non-Hijazi form. 
Further evidence for a lack of correlation of readers to any one dialect may be found among lexical isoglosses. Al-Farrā? (Lug̈ăt) discusses many differences between the dialects in the vocalism of specific lexical items. In most cases these seem to be different stem formations, in line with a certain freedom of stem formation seen across the Semitic languages (Fox 2013, $102 \mathrm{ff}$.). With such cases we once again find significant disagreement among the readers, where each of the readers incorporates forms from a variety of different dialects. I will discuss these variants in the list below. Each lexical item will be listed with the tribe or region its associated with, followed by the page number where this is mentioned in al-Farrā?'s work. After that the reading that has the fewest readers in agreement is mentioned. The unmentioned remainder then has the remaining form.

1. nabtušu (Hijaz), nabtišsu (?asad), p. 24. Pabū Ğa9far:nabțušu (Ibn al-Ğazarī $\S 3162)$.

2. maysurah (Hijaz), maysarah (Tamìm, Qays, and people of the Najd), p. 41. Nāfi؟: maysurah (Ibn al-Ğazarī, § 2811).

3. buxul (Hijaz), buxl (Tamīm), baxal (Tasad), baxl (Tamīm, Bakr b. Wā?il), p. 54f. Ḥamzah, al-Kisā?ī and Xalaf: baxal. Rest: buxl (Ibn al-Ǧazarī, §2930).

4. hiṣād (Hijaz), haṣād (Najd and Tamīm), p. 63. Yāṣim, Rabū Yamr, YaYqūb, Ibn Yāmir: hasạ̄ad (Ibn al-Ǧazarī, § 3०76).

5. rubamā 'perhaps' (Hijaz), rubbamā (Tasad, Tamīm), rabbamā (Taym alRabāb from Tamīm), p. 78. ؟āṣim, Nāfiৎ, Rabū Ğaffar: rubamā. Rest: rubbamā (Ibn al-Ǧazarī, §339o).

6. ka-Payyin (Hijaz), kā?in (Tamīm), p. 101. Ibn Katīir, Pabū Ğalfar: kā?in (Ibn al-Ğazarī, § 2875).

7. fawāq (Hijaz), fuwāq (?asad, Tamīm, Qays), p. 123. Ḥamzah, al-Kisā?ī, Xalaf: fuwāq (Ibn al-Ğazarī, §4057).

8. $\quad \operatorname{salm}$ (Hijaz, Tamìm, Pasad), silm (Qays), p. 131. ŠuSbah Yan Yāșim (Q2:208; Q8:61; Q47:35), Ḥamzah, Xalaf (Q47:35): as-silmi (Ibn al-Ğazarī, § 2761).

9. wuğd (Hijaz), wağd (Tamīm), p. 141. Rawḥ Yan Yåqūb: wiǧdi-kum (Ibn alĞazarī, § 4409), the rest has the Hijaz form.

10. nașūh (Hijaz), nuṣūh (some of Qays), p. 141. ŠuSbah Yan Yāṣim: nuṣūhan (Ibn al-Ğazarī, § 4417).

11. tafāwut (Hijaz), tafawwut (some Arabs), p. 142. Ḥamzah, al-Kisā?ī: tafawwut (Ibn al-Ğazarī, § 4420).

12. ruğz (Hijaz), riğz (Tamim and the common people of the Arabs), p. 147. Hafṣ Yan Yāṣim, Pabū Ğaffar and YaYqūb have ar-ruğza (Q74:5) (Ibn alĞazarī, § 4472).

13. watr (Hijaz), witr (Qays, Tamīm, Rasad), p. 157. Ḥamzah, al-Kisā?ī, Xalaf: wa-l-witri (Q89:3) (Ibn al-Ǧazarī, § 4547). 


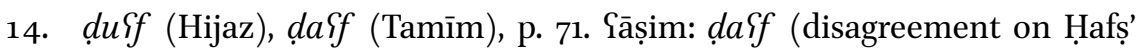

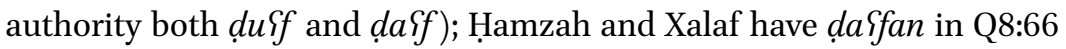
but duৎf(an) in Q30:54; Pabū ĞaSfar has dufafā? in Q8:66, dụf in Q30:54 (Ibn al-Ğazarī, §3898). The rest has the Hijaz form in all positions.

15. Puffin, ?uffi (Hijaz), ?uffa (People of Yemen and Qays), ?uffu (Some Arabs), Puffan (?asad), p. 8o. Ḥafș Yan Yāșim, Nāfị, ?abū ĞaYfar: ?uffin. Ibn Kațīr, Ibn Yāmir, YaYqūb ?uffa; The rest: ’uffi (Ibn al-Ǧazarī, § 3457).

16. mansak (Hijaz), mansik (most from Najd), p. 99. Ḥamzah, al-Kisā?ī, Xalaf: mansikan (Ibn al-Ǧazarī, § 3657 ).

17. hayhāta (Hijaz), Payhāti(n), hayhāti(n) (Tamìm, Pasad), ?ayhātan (some Tamīm), Payhāta, Payhātun, Payhātu, Payhāna (some Arabs), p. 102. Pabū ĞaYfar: hayhāti. The rest has the Hijaz form (Ibn al-Ğazarī, §3689).

18. wuddan (Hijaz), waddan (Tasad), p. 145. Nāfiৎ, Rabū Ğaffar: wuddan, the rest has waddan (Ibn al-Ğazarī, §4452).

As with the sound laws discussed in the previous section, it is clear that the reading traditions are highly mixed, showing features of different dialects. There is not a single 'base' from which readers have then occasionally imported regional dialectisms. In fact, one frequently finds the opposite trend. For example, in the case of reading ka-?ayyin versus kā?in, we find that only the Hijazi readers have the Najdi forms, while all the non-Hijazi readers have the Hijazi forms. Likewise, the readers whose pronominal systems contain the most Hijazi forms are Hamzah (Kufa) and YaYqūb (Basra), whereas all the Hijazi readers have perfectly Najdi forms.

Assuming that there was a single 'standard' Sarabiyyah — which for some reason does not get explicitly described by the grammarians - we would have to conclude that readers are moving away from an accepted standard by incorporating features that were explicitly not local to them. Considering the complete silence of the grammarians of this single standard, this strikes me as an assumption we cannot make based on the evidence at hand. Rather, the data seems to suggest that through a process of imperfect transmission and explicit choices, the readers assembled their own reading of the Quran, with no regard as to whether this amalgamation of linguistic features had ever occurred in a single dialect of the Sarabiyyah.

\subsection{Readers Usually Agree on the Hijazi Form}

So far, we have discussed many phonological, morphological and lexical isoglosses that are reported as differences among the Arabic dialects by the Arab grammarians. We see that very often readers have no real consensus on what 
dialectal form to use, and that even within a single reading, an alternation between different dialectal forms occurs. These disagreements are frequent and clearly show that the Quranic readings cannot be thought of as "dialects" of Arabic. Nevertheless, there are still many examples where al-Farrā? mentions differences in specific words and grammar, where all the readers are in agreement amongst one another.

One might imagine that the points where the readers agree with one another is what could be considered the "Classical Arabic" base. However, whenever such consensus exists, almost invariably, the readers agree on the form attributed to the Hijaz. These cases clearly far outnumber the cases where there is disagreement among the canonical readers. By and large the basis of all the Quranic readings therefore seems to be Hijazi Arabic. This is already clear from some of the classes discussed above. While CuCuCāt forms do show a couple cases where the Najdi syncopated CuCCāt form is employed, the majority of the cases show agreement among the readers on the Hijazi form. The same is true for $\mathrm{CuCuC}, \mathrm{CaCiC}(\mathrm{ah})$ nouns, $\mathrm{CiCwān} \mathrm{nouns} \mathrm{etc.}$

In cases of complete agreement among the readers, the consensus almost always falls upon the Hijazi form. For example, the grammarians inform us that the initial vowel of the prefix conjugation of verbs is $i$ when the second vowel is $a$ (i.e. Pifhamu 'I understand') among the Tamim, whereas the Hijazis have the innovative $a$ vowel there (i.e. ?afhamu) (see $\S 2.2 .5$ ). There is consensus among the canonical readers to read all of these forms in the Hijazi manner.

Also, when it comes to lexical isoglosses, the vast majority of the cases mentioned by al-Farrā? there is consensus on the Hijazi form. Below follows a list of some of the words where two local variants are mentioned by al-Farrā? but where the canonical readers consistently opt for the Hijazi form. The page number is the page where the form occurs in al-Farrā?'s Lugāt.

- zuğāğāh (Hijaz), zağāğah, ziǧăǧah (Tamīm Qays), p. 107.

- tuxsirū (Hijaz), taxsirū (?asad), p. 136.

- šararah, šarar (Hijaz, Rasad), šarārah, šarār (Tamīm, Qays), p. 151.

- șulb (Hijaz), șalab (?asad, Tamīm), p. 155.

- musayțir (Hijaz, ?asad), musaytar (Tamīm), p. 156.

- kidta (Hijaz), kudta (Common people of Qays), p. 81.

- baSudat (Hijaz), baSidat (Some of Qays), p. 71.

- ğuhd (Hijaz), ğahd (Tamìm), p. 72.

- gilzah (Hijaz, Rasad), gulzah (Tamìm), p. 72.

- miryah (Hijaz), muryah (Pasad, Tamim), p. 74.

- qațirān (Hijaz, Pasad), qițrān (Some of Tamīm and Qays), p. 77 .

- $\operatorname{surur}$ (Hijaz), surar (Tamim, Kalb), p. 78. 
- šağar (Qurayš and its neighbours of the people of the Hijaz), šiǧar (the common people among the Arabs), p. 79 .

- sukārā (Hijaz, ?asad), sakārā (Tamīm), p. 55.

- kusālā (Hijaz), kasālā (Tamīm, Pasad), p. 59.

- yurā?ā (Hijaz), yura??āa (the common people of Qays, Tamīm and Pasad), p. 37

- al-hady (Hijaz, ?asad), hadiyy (The Tamim and lowest of the Qays), p. 34.

- al-qittāâ (Hijaz), al-quttāâ? (Tamīm and some of the ?asad), p. 25.

- maxād (Hijaz, Rasad), mixā d (Tamīm, Qays), p. 89.

- laSalla (Hijaz), laSalli (Some of ?asad), p. 103.

- nisf (Hijaz), nusf (?asad, Tamīm), p. 42.

- hūb (Hijaz), hawb (Tamīm), p. 54.

- Patar (Hijaz), Pittr (Najd), p. 58.

- min Pağl (Hijaz), min Piğl (Tamīm), p. 62.

- zaßm (Hijaz), zuৎm (?asad), zi

- The contextual form of the first-person pronoun: ?ana (Hijaz), ?ana (Arabs, Qays, Rabīiah), p. 64.

- itnatā Yašrah (Hijaz, Pasad), ițnatā Saširah (Rabīiah b. Bizār, Tamīm), p. 24. Cases where all readers agree on the non-Hijazi forms are rare. So far, I have only identified two cases:

- ğubullah (Hijazi), al-Farrā? reports the reading of Yāșim and al-Paimaš is gibillah, p. 110. It is also the reading of the other readers.

- baxalat (Hijaz), baxilat (Arabs), p. 53. Consensus on baxila.

\subsection{The Readings Are Intentionally Artificial}

As we have seen above, none of the readings make up any single consistent linguistic system, nor do they show a clear signal of any one dialect of Arabic. Instead, they are an mix of different dialectal forms, distributed in a way from which no obvious pattern can be deduced. The linguistic character of the reading traditions appears to be the result of an artificial amalgamation of different features. In the following sections we will develop this further. We will argue that the irregular patterns we see are not just the result of perhaps faulty - transmission, but that this configuration of exotic features was to some extent the express purpose of the readers. The lack of regular patterns in the application of sound laws as we saw in $\S 3.3$ could be understood as the result of unintentional mixing. One may imagine that native varieties interfering with incomplete and conflicting reports on how to recite certain words in the context of a nascent grammatical theory could lead to such mixing, 
although the reasons and patterns cannot meaningfully be deduced from the reading traditions as they have come down to us.

However, this cannot account for all linguistic variation among the reading traditions. In several cases we find that certain general rules that are operative in the readings are highly dependent on Arabic grammatical theory. And it is difficult to imagine how users of the language could have employed these rules before the development of this theoretical framework. In other cases, we find examples of complex conditioning that is dependent not on grammatical theory but on the very structure of the text, keeping in mind strictly where the verse divisions are, for example. Finally, there are many cases of lexical specification of certain sound laws. In several cases, readers will follow a regular phonological rule, only to be broken a single time in a single word. In several cases this involves words that occur in their regular form elsewhere in the text.

Such features do not point to a genuine (and perhaps failed) attempt to transmit the Quran verbatim, as, for example Versteegh $(1984,10)$, following Beck $(1945 ; 1946)$ claims the situation was in the first half of the 8th century CE. Rather, such features should be seen as a deliberate attempt at showcasing a reader's knowledge of the text and grammar, including complex structures not otherwise attested within the description of Arabic.

Many of the general principles that take place in the Quranic readings are only made possible because Arabic grammatical theory allows readers to formulate complex grammatically conditioned changes. But this does not mean that the Quranic readings fall within the purview of the descriptions of the Arab grammarians. While much, if not all, of the linguistic variation that we find in the Hadith and poetry fall within the possible variations described by the grammarians, the reading traditions very often have features and linguistic rules that transcend the boundaries of linguistic variation that the Arab grammarians describe. ${ }^{36}$ Moreover, the readings often go beyond what we might expect to occur in natural language. In the following sections I will describe some of the artificial features as they are present in the Quranic reading traditions.

36 While this statement strikes me as true in principle, I warn the reader not to essentialize it too much. The Quranic readings have a complex and specialized oral and written tradition that keeps track of highly specific phonological and morphological rules that govern these readings. The Hadith and poetic corpus do not enjoy the same specialized tradition when it comes to communicating specific linguistic facts. It may very well be the case that these corpora also had linguistic features that go beyond what the grammarians describe; the incessant move towards classicizing these corpora as already pointed out by Rabin $(1955,21)$ to norms stricter than what the Arab grammarians allow, and more towards the 


\subsubsection{The Dropping of the Hamzah by Wař̌}

Warš, one of the two canonical transmitters of Nāfị, is well known for his frequent dropping of the hamzah with compensatory lengthening such as ya?kulu > yākulu, yasta?xirūna > yastāxirūna or with the replacement with a glide when the hamzah occurs intervocalically yuiaxxiru-hum > yuwaxxiru-hum. Regular dropping of the hamzah is by no means unique to Warš. Pabū ĞaYfar regularly and ?abū Yamr optionally drop any pre-consonantal hamzah (Ibn al-Ğazarī, §1466; §1472-1474). However, the dropping of the hamzah of Warš' tradition is not universal. It exclusively applies to the hamzah when it is the first root consonant, thus he reads yākulu but ar-ra?su; mümin and muwaddinun but lu?luịan (Al-Dānī taysìr, 34; Ibn al-Ğazarī, II, 123of., 1240 f.). The difference between first, second and third root consonants is a morphological one, and a concept that was known to medieval grammarians, but not something that we would expect to be a factor in natural language change. In historical linguistics, we consider language change as taking place on the phonological surface form, and being purely phonetically conditioned (Hock 1991, 34-51); this is not the case for Warš' dropping of the hamzah, as it is dependent on grammatical theory. This way of recitation therefore cannot have been introduced before the development of Arabic grammatical theory, and therefore cannot be projected back to manners of recitation among the first generations after the standardization of the Quran.

\subsubsection{The Pimālah of Word-Final Āri Sequences}

A similar case of sound change dependent on grammatical theory is found with the raising of $\bar{a}$ to $\bar{e}$ (Pabū Yamr; al-Dūrī Yan al-Kisā?ī; Ibn Dakwān Yan Ibn Yāmir) or $\bar{a}$ (Warš Yan NāfiY) next to ri. This rule, which clearly represents a kind of $i$-umlaut, occurs for several different readers, but their principles all have one thing in common: $\bar{a} r i$ only raises if the $r$ is the third root consonant, or formulated differently: if $-i$ is the vowel that marks the genitive case (al-Dāni Taysìr, 51; Ibn al-Ǧazarī, § 2046-2062).

On the surface, this type of Pimālah looks very similar to the Pimälah involving āri as described by Sībawayh (see $§$ 2.2.2.1 and Sïbawayh, IV $136 \mathrm{ff}$., Sara 2007, $82 \mathrm{ff}$.). While to Sïbawayh the sequence $\bar{a} r i$ is stronger than other sequences of $\bar{a} C i$, and therefore can undergo Pimālah for example if the preceding consonant is uvular or emphatic, it is clear from his description that those that have Pimālah of the sequence āri also have it, for example, in kātib $>$ kètib.

standard form of Classical Arabic make it very difficult to judge to what extent the material can be trusted. These corpora deserve an in-depth and careful study of their features too. 
However, the readers that have this type of Pimālah exclusively apply it with $\bar{a} r i$, and not with other sequences.

Even if one does not accept that āri Pimālah applies only in dialects that have other forms of Pimālah too (Sïbawayh is not very explicit about this), the behaviour in the readings is still markedly different from what Sỉbawayh describes. While the genitive case vowel can indeed cause Pimälah e.g. min

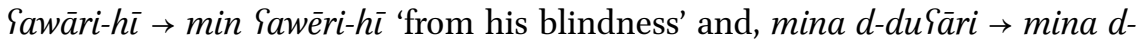
duferri 'from dizziness', it is by no means the case that only the genitive $i$ can be the cause of this Pimālah, thus Sībawayh cites forms like qārib $\rightarrow$ qerib 'boat' and țārid $\rightarrow$ têrid 'expeller'.

For none of the Quranic readings however, such word-internal äri Pimālahs take place. Thus we see nārin $\rightarrow$ nērin 'fire' (Q7:12; Q22:19; Q38:76; Q55:15, 35); an-nahäri $\rightarrow$ an-nahēri 'the day' (Q2:164) but not active participles like laysa bi$x$ āriğin $\rightarrow$ **laysa bi-xēriğin 'not coming out' (Q6:122), al-wāriț $\rightarrow$ **al-wērit 'the heir' (Q2:233), or verbs like yuhāribūna $\rightarrow$ **yuhêeribūna $\left(Q_{5}: 33\right),{ }^{37}$ ?uwāriya $\rightarrow$

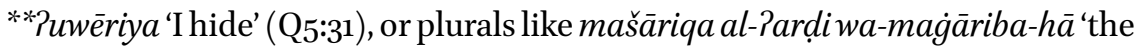
eastern regions of the land and the western ones' (Q7:137). These are all forms that would undergo this development if we would follow Sïbawayh's description. While one can envision that in such productive morphological patterns, the forms without Pimālah might be analogically levelled to forms that are otherwise expected to undergo Pimālah, ${ }^{38}$ such an explanation cannot be invoked with all nouns that fail to undergo the àri îmälah. For example, al-hawāriyyina (Q5:111) al-hawāriyyūna (Q5:112; Q61:14), li-l-hawāriyyina (Q61:14) 'the disciples' is a unique noun formation due to its status as an Ethiopic loanword (< Gə९əz häwari 'traveler'). It seems that the $\bar{a} r i$-Pimālah found among the readers is an artificial rule that requires a clearly developed grammatical theory. Those who apply need to distinguish when a certain sequence is a final root consonant, something that would not be possible without the formal linguistic model of the consonantal root.

The extent of grammatical thinking that is involved in the application of this rule becomes clear when we examine nouns with the exact same phonetic

\footnotetext{
37 Note however that prefix conjugation forms of sāraSa 'to hasten' undergo Pimālah in the reading of al-Dūrī Yan al-Kisāī̄ yusēriৎūna (Q3:114, 176; Q5:41, 52, 62; Q21:90; Q23:61), nusēriิu (Q23:56) (Ibn al-Ğazarī, §198o).

38 A development in the opposite direction is found in Maltese, for example, where all active participles undergo Pimālah, even if they historically contain consonants that would

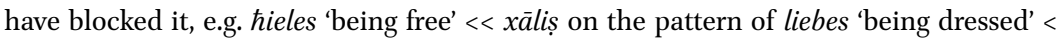
lābis, while lexicalized words of this pattern do have blocked Pimālah: ћakem 'governor'< hākim.
} 
shape with $\bar{a} r i$ word-finally, but where the $-i$ is not the genitive case vowel. A word like al-ğawäri 'the ships' (Q42:32; Q55:24; Q81:16) is not included in this

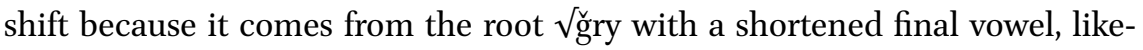
wise it is not applied to fa-lā tumāri 'do not argue' (Q18:22) because the root

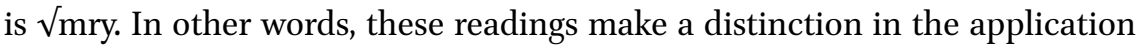
of Pimālah depending on whether the final $-i$ is ğarr/xaf̣̣ (the inflectional $-i$ ) or kasr (the non-inflectional $-i$ ), and is thus morphologically rather than phonetically conditioned. This conditioning therefore does not look like a natural sound change, and moreover, falls outside the purview of what the Arab grammarians describe.

The other transmitter of al-Kisā?ī, ?abū al-Ḥārit has an even more specific conditioning for āri-Pimālah. He only applies Pimālah in these cases if the last root consonant is an $r$ followed by the genitive $i$, but only if the root under consideration is a geminate root, so al-Pabrāri $\rightarrow$ al-Pabrēri but not al-Paxbāri $\rightarrow{ }^{* *}$ al-Paxbēri (al-Dānī Taysìr, 51; Ibn al-Ğazarī, III, 1676). Such specific conditioning of Pimälah falls completely outside of the types of Pimälah described by the Arab grammarians.

\subsubsection{Vowel Harmony of -hum in Ruways San Ya Sqüb's Reading}

Another illustrative example where we see the reading traditions in dialogue with the grammatical tradition, leading to an artificial treatment of the pronominal suffixes is the one found in Ruways' transmission of YaYqūb. Yaiqūb's basic rules shared between his two transmitters, Rawh and Ruways, already fall well outside of the kind of variation that Sībawayh and other grammarians describe. To the grammarians it is clear that $i, \bar{l}$ and ay preceding either the singular or plural pronouns may trigger vowel harmony (yielding -hi, -hi, -him, -himā, etc.) or may be avoided, as is the Hijazi practice. YaSqūb, however, has a different kind of conditioning. For the 3rd person singular ending, the conditioning is harmonized as with all other readers if it follows $i, \bar{l}$, and ay (Ibn al-Ǧazarī, §1210-1212). But for the plural, the conditioning is different and only $i$ triggers vowel harmony. ${ }^{39}$ Thus, one gets: bi-hī /bi-him, fi-hil fi-hum and Salayhi/Salay-hum (Ibn al-Ğazarī, §1120). This pattern is not described by the Arab grammarians, and is specific to this Quranic reading tradition. ${ }^{40}$ It is difficult

39 YaYqūb's direct teacher, Sallām Pabū al-Mundir (d. 171/788) conditions the harmony of the singular in the same way as the plural, where only $i$ but not ay and $i$ trigger vowel harmony (van Putten and Sidky forthcoming).

40 In fact, it is also attested in several other non-canonical Basran reading traditions, see van Putten \& Sidky (forthcoming). 
to envision such conditioning as a natural development. It rather seems to be a concerted effort of the reader to have an exotic and complex harmony rule.

Ruways takes this exotic conditioning even further. Because the apocopate of final weak verbs is envisioned in grammatical theory as shortened forms of the long imperfect stems, that is, ya?ti is considered a shortened form of ya?ti, Ruways treats these forms as having a long vowel, and thus final weak apocopates block vowel harmony of -hum, while other cases of final - $i$ do not, thus Ruways reads: bi-him, bi-danbi-him but lam yaiti-hum (Ibn al-Ǧazarī, §1121). Making a morphological distinction between word-final $-i$ that is part of an apocopate and that which is not. The vowel harmony is clearly dependent on Arabic grammatical theory and a model of the 'apocopate', and must be seen as artificial.

\subsubsection{Hafș' Anthology of Unusual Features}

Nowhere is the artifice of the Quranic reading traditions so apparent as in the readings of Hafṣ Yan Yāṣim. Hafṣ’ general principles, grammar and morphology to a large extent agree with Classical Arabic. While this classical and standardized look is striking, it is even more striking that more than any other reader, Hafș' reading has a very specific and clearly calculated incorporation of single lexical items that break his general rules by incorporating a feature typical of other Quranic readings. Such features are used in determined places, usually only once and occasionally twice in the whole of the Quran. This clearly conscious, and we may even say playful, use of language was already observed in a footnote of an article by Laher (forthcoming), but it is worthwhile here to expand on this observation and give it a full description.

\subsubsection{1 Șilat al-hā? (Q25:69)}

A unique feature of the reading of Ibn Katīr is that he has long vowels in the third person singular masculine pronoun $-h \bar{u} /-h \bar{\imath}$ which are not shortened after a heavy syllable as we find it among the other readers. While Hafṣ follows the general practice of shortening of the $-h \bar{u} /-h \bar{\imath}$ after a heavy syllable, he has a single exception, namely in Q25:69 he reads فيه 'in it' not as fi-hi as he does in the 129 other occurrences of this word, but as $f \grave{\imath}-h \bar{\imath}$ (Ibn al-Ğazarī, §1212).

\subsubsection{III-y Pimālah (Q11:41)}

Unlike the other Kufans, Hamzah, Xalaf and al-Kisā?ī, Yāṣim does not regularly have Pimālah for III-y verbs and nouns. Hafș, however, makes a single exception to this, namely in the word mağrē-hà 'its course' in Sūrat Hūd (Q11:41) (Ibn al-Ǧazarī, § 1992). 


\subsubsection{Softening of Second Hamzah of Two Subsequent Hamzahs (Q41:44)}

It is typical of the Kufans and Ibn Yāmir to not weaken the hamzah when two vowelled hamzahs follow each other; This is different from the other readers which lose the second hamzah, and instead create a hiatus (tashil al-hamzah). Hence, Hamzah, al-Kisā?ī, Xalaf, Yāṣim and Ibn Yāmir all read Q2:6 ?a-Pandartahum 'do you warn them?', where the other readers read $? a$ andartahum, ?āa-andartahum or even ?āndartahum (Warš) (Ibn al-Ğazarī $\S 1384-1387$ ). However, Hafș, unlike the other Kufans, makes a single exception: he reads Q41:44 as ?a-a९̆ğamiyyun with hiatus (Ibn al-Ğazarī § 1394).

\subsubsection{Muttum instead of Mittum (Q3:157, 158)}

There is disagreement among the readers on how the verb māta 'to die' should be treated in the short stem of the suffix conjugation. Ibn Katīir, Pabū Yamr, Ibn Yāmir and ŠuYbah Yan Yāșim all read it with a dammah, that is muttum, muttu, mutnā whenever they occur; On the other hand, Ḥamzah, al-Kisā?ī, and Nāfi read it as mittum, mittu and mitnā whenever they occur. Hafș generally follows the $i$-norm, but in the two attestations in Sūrat Pāl Simrān $(\mathrm{Q} 3: 157,158)$, he chooses to use the $u$-norm instead muttum instead (Ibn al-Ǧazarī, § 2881).

\subsubsection{Unharmonized -hu (Q18:63; Q48:10)}

All canonical readers are in agreement that after $i, \bar{\imath}$ and ay the third person masculine pronoun should undergo vowel harmony and be reflected as - $h i$ (or - hī for Ibn Kațīr). While Ḥafș usually just applies vowel harmony as expected, he has two exceptions, one after $\bar{\imath}$ and one after ay: mā $\vec{P} a n s \bar{a}-n \bar{\imath}-h u$ 'he did not make me forget it' (Q18:63) and Salay-hu 'upon it' (Q48:10) (Ibn al-Ǧazarī, $\S 1212) \cdot{ }^{41}$

\subsubsection{III-y/w Apocopates/Imperatives Followed by the 3sg.m. Pronoun}

As we will see in $\S 7.1 .8$, there is disagreement between the readers on how to treat the vocalization of the 3 sg.m. clitic pronoun when it follows an apocopate or imperative of a III- $y / w$ verb. Hafș as a general rule follows the Classical Arabic rule, which simply uses the long pronouns $-h \bar{\imath}$ after $-i$ and $-h \bar{u}$ after $-a$, e.g. yu?addi-hī 'he returns it' (Q3:75), lam yara-hū 'he did not see it' (Q90:7). Other readers either have shortened pronouns $-h u /-h i$, or have a fully unvocalized pronominal form $-h$. Hafș however has occasional exceptions to this

41 A few other readers have a similar lack of harmony in a few cases. Hamzah reads li-Pahlihu mkuțū (Q20:10; Q28:29) and in the transmission of al-Paṣbahānī for Warš Yan NāfiY we find bi-hu nzur (Q6:46) (Ibn al-Ǧazarī, § 1232). 
general rule, instead following the practices of other readers. So, he reads $f a-$ Palqi-h 'so deliver it!' (Q27:28), ?arği-h 'postpone him' (Q7:111; Q26:36) without a final vowel (typical of Pabū Ğaffar, Pabū Yamr, ŠuSbah Yan Yāṣim), yarḍ-hu 'he likes it' (Q39:7) with a short vowel (typical of Qālūn Yan Nāif and YaYqūb). Moreover, he uniquely reads yattaq-hi 'he fears him' (Q24:52) with dropping of the apocopate vowel, and a following pronoun still harmonized as if the preceding vowel was present. None of the canonical reading traditions show that behaviour, and it is irregular in his reading as well (Ibn al-Ğazarī, §1217).

\subsubsection{Conclusion}

These features listed above are isolated in the transmission of Hafș, and they are moreover unique among the transmitters of Yāșim. Neither ŠuSbah nor the extensively described non-canonical transmitter al-Mufaḍal have such a wide collection of 'one-off' exceptions to their general rules. It therefore seems that these isolated readings by Hafș are innovations introduced by him, and should probably be considered conscious 'homages' to other readings that were around in his lifetime, showing off not only his knowledge of grammar but also the knowledge of linguistic variation present in the Quranic reading traditions.

\subsubsection{Plural Pronouns of Warš}

Sībawayh (IV, 191) and al-Farrā? (Lug àt, 33), and with them many other grammarians (see van Putten and Sidky forthcoming) are in agreement that the plural masculine pronouns such as hum, 'antum, -tum, -hum, -kum may optionally be followed by a long vowel $-\bar{u} .^{42}$ Both grammarians present this as this basically being a free option, and in poetry we indeed find both forms used within the same text, as the meter requires it. Some of the canonical readers regularly have these lengthened forms. This appears to have been typical for the reading traditions of the Hijaz. Both Pabū ĞaYfar and Ibn Katîir use it regularly (see Ibn al-Ǧazarī, §1122). For Nāfî, Ibn Muğāhid (108f.) reports that Qālūn (and along with him, now non-canonical transmitters such as ?ismāYīl b. ĞaYfar, Ibn Ğammāz and al-Musayyabī) all optionally pronounced it either in the short or long form. ?aḥmad b. Qālūn $\leftarrow$ Qālūn said "NāfiY used to find no fault in

42 An outstanding question is how these long pronominal forms should be understood in light of comparative Semitic evidence. While most Semitic languages have the short forms of these pronouns, Ancient South Arabian generally attests long forms (but occasionally short forms are attested), as does GəYəz and Akkadian. The situation reported for Classical Arabic, which seems to have both forms, is not detailed enough to recover how these forms relate to one another. 
adding the vowel to the mimm." From which Ibn Muğāhid concludes that NāfiY's original reading was without the vowel, and he reports that he himself reads in this way.

Warš, however, uses both the long and short forms of the pronominal suffixes, and these are phonetically conditioned: Whenever a ? immediately follows, Warš uses the long forms (Ibn al-Ǧazarī, § 1123; Ibn Muğāhid 108f.). While this conditioning is purely phonetic it is not altogether easy to recover what exactly would have caused this. Even if we assume that the Proto-Arabic form was *-humu etc. there is nothing about a ? in the following word that would cause it to be lengthened, nor is its absence an obvious reason for syncopation. It seems rather that Warš made the explicit choice to incorporate both options condoned by Nāfi and constructed this condition in order to be able to accommodate both options in a single recitation, where, when reciting in the transmission of Qālūn, one chooses either for the long or the short forms of the pronouns.

A distinct euphonic motivation of this choice by Warš must certainly be considered. ${ }^{43}$ Warš' recitation is well-known for its excessive use of overlong vowels. Overlong vowels (madd) in Tajwìd are applied by all readers to long vowels that precede hamzah and shaddah (samāāêu, aḍ-d̄āallīna) (Ibn al-Ǧazarī § 1234-1238). Warš, together with Hamzah, is said to have had the longest overlong vowels (al-Dānī Taysìr, 30). Unlike all other readers, Warš also lengthens long vowels if they are preceded by hamzah, thus yielding Pāādamu (versus the rest Pādamu) (al-Dānī Taysìr, 31), and even to diphthongs followed by hamzah, e.g. šayyyy?un and sawwwwwiata (al-Dānī taysīr, 72). Moreover, unlike some other readers (Ibn Kațīr, Qālūn (with disagreement) and as-Sūsī do not do this), Warš would also lengthen long vowels if the hamzah is the beginning of the next word, thus māa ?unzila. All of these features give the recitation of Warš a very distinct stretched out sound compared to all other readers. Due to Wars' application of overlong vowels if the next word starts with a hamzah, Wars' specific conditioning of the long pronouns to only appear before hamzah gives him yet another opportunity to apply his signature madd.

Therefore, Warš seems to have adapted available linguistic options but has reconfigured them in a way that seems to have been unique to Quranic recitation. While descriptions of the reading traditions use the same terminology and categories as the grammarians, the phonological and morphological phenomena that are found go far beyond what we find in the descriptions of the grammarians. Therefore, if we are to accept that the Quranic readings really 
did form subsystems of the Sarabiyyah, it was either not considered eloquent enough to be considered farabiyyah by the grammarians, or the grammarians were woefully incomplete. Considering both the high regard for these readings and the breadth of knowledge displayed by the earlier grammarians, neither scenario should be considered particularly plausible.

This is an important point: while the descriptions of the reading traditions use the same terminology and categories as the grammarians, and are able to describe the variation found in the readings within this framework, at no point do the descriptions of the reading traditions invoke the mention of dialects that may have had the same system as these readings. Similarly, grammarians never describe such patterns of pronominal use as found in, for example, the reading of Warš as acceptable (or unacceptable) for the farabiyyah. This system stands on its own, separate from the grammatical theory of Arabic, going beyond what is considered the "regular" Sarabiyyah that the grammarians would comment upon.

\subsubsection{Features Dependent on the Structure of the Text}

Besides the features discussed above that mix and match phonological and morphological features in clearly artificial ways from a historical linguistic point of view, there are several cases where the reading traditions specifically rely on the structure of the text, which seems to be designed to show off the in-depth knowledge of this text.

\subsubsection{Tabū Yamr's Phonemic Contrast of Ā and $\bar{A}$}

Pabū Samr's Pimālah of III- $y$ verbs and nouns is another clear example of the Quranic readings not being interpretable as the outcome of natural language change, as it is dependent on which position in the verse a word occurs. While Pabū Yamr usually merges the ?alif maqșūrahs of III- $y$ versus III- $w$ stems and etymological ${ }^{*} \bar{a}$ (whereas other readers such as al-Kisā? $\overline{1}$, Hamzah and Warš Yan Nāfi always keep them distinct), he keeps them distinct exclusively in versefinal position - which by extension accommodates the rhyme of several Sürahs that rhyme in Quranic Arabic /-ē/, for example, prominently Q20, Q53, and Q91. Whenever a III- $y$ verb or noun occurs at the end of a verse, it is pronounced with $\bar{a}$ (Ibn al-Ğazarī, § 1986). ${ }^{44}$

It is not uncommon for specific sound changes to take place only in pausal position. This is even fairly common among the modern Arabic dialects. For

44 There are also transmitters of al-?azraq $\leftarrow$ Warš $\leftarrow$ Nāfi that only uses $\bar{a}$ in verse final position, and not elsewhere (Ibn al-Ğazarī, § 2017, § 2022-2023). 
example, we find palatalization of ${ }^{*} t$ in Shammari (van Putten $2017 \mathrm{~b}$ ), glottalization in Sanaani (Watson and Heselwood 2016) and vowel lengthening in Levantine dialects (Fischer and Jastrow 1980, 179) all taking place specifically in pause. However, in the case of ?abū Yamr's reading we are not dealing with a sound change that takes place in this position, but rather the absence of merger in this position, while the two sounds merge in other positions. ${ }^{45}$

A lack of a merger of a phonemic contrast in pause, while the merger is found in all other positions is rare cross-linguistically. The only other parallel that comes to mind, where however it has become a part of morphology, rather than a phonemic contrast that is retained, is found in another reading tradition of a holy text, namely that of Biblical Hebrew. There, stressed short vowels in pause get lengthened to long vowels. This lengthening precedes certain later stress shifts that took place, and therefore historical vowels that are lost elsewhere show up as long vowels in pause (Suchard 2019, $115 \mathrm{ff}$.). However, in Hebrew such pause-conditioned variants have mostly morphologized and do not generally revive phonemic contrasts lost everywhere else. ${ }^{46}$ Suchard $(2019,115)$ expresses doubt that this kind of contrast could have been obtained in natural speech where such contrasts would have quickly been leveled by analogy. I agree with this assessment, and by extension it is particularly difficult to imagine that ?abu Samr's results from natural language use, as he retains a phonemic contrast only in rhyme position, and nowhere else.

Even if the reciter chooses to not pause at the end of the verse, the contrast needs to be maintained, and pausing on non-verse final recommended pauses of III- $y$ nouns or verbs does not cause them to be read with $\bar{a}$. The phonemic distinction introduced by ?abu $\mathrm{Camr}$, then, is specifically conditioned by the structure of the text, making a distinction between verse-final pauses and other types of pauses. This should probably be understood as a conscious awareness of ?abū Yamr (or perhaps his main transmitter al-Yazīìi) to harmonize the clear end rhyme in /ē/ of some of the Sūrahs (van Putten 2017a, 57 f.), while otherwise maintaining a preference for merging the two sounds into a single $\bar{a}$-perhaps

45 There are in fact a few other positions where Pabu Samr retains the contrast. Namely in the case of feminine nouns with the shape $\mathrm{Ca} / \mathrm{i} / \mathrm{uCC} \overline{\tilde{a}}$, and whenever the consonant preceding it is $r$, in which case it is pronounced as $\bar{e}$ (see Ibn al-Ǧazarī, § 1986, § 2032). These too can hardly be considered regular outcomes of sound change, and present situations beyond what the grammarians discuss.

46 The occasional distinction between *CaCC- and *CiCC- nouns that have merged in nonpausal independent position being the only clear example of an ancient phonemic con-

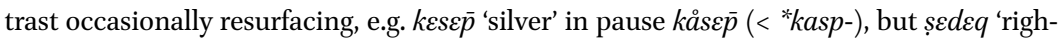

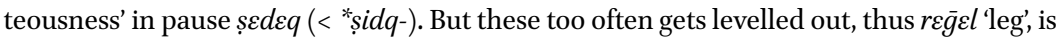
råg $g l$ in pause, despite coming from *rigl- not **agl-. 
anticipating the trend that has led to the now standard form of Classical Arabic which does not have a distinction between these vowels.

\subsubsection{The Verse-Penultimate Conditioning of Qutaybah and Nuṣayr San al-Kisā?ī}

Two transmitters of al-Kisā?ī that do not make it into the two-rāw $\bar{c}$ canon but are nevertheless described in quite some detail in more extensive works like alDān's's Ğāmi al-Bayān and Ibn Mihrān's al-Ġāyah and al-Mabsūt are Qutaybah and Nușayr (Ibn Mihrān Ġāyah, 141 f.; al-Mabsūt, 89). Both of these transmitters, unlike the canonical transmitters of al-Kisā?ī, make use of the long forms of the plural pronouns. There are some minor differences, especially in the precision of the description, between al-Dānīs Ğāmi and Ibn Mihrān's works. I will limit myself to the description of al-Dānī ( $\breve{a} \bar{a} m i \varsigma, 16$ off.).

For Nuṣayr, the plural pronoun is eligible for the use of long pronouns:

A. If it is unharmonized, i.e. -hum does not follow $-i^{-},-\overline{-}$ or $-a y$-. Non harmonizing pronouns like -kum are therefore not affected by this condition.

B. If the word it is attached to consists of five letters or fewer as written in the Muṣaf (but he did not count wa- and $P a$ - as part of the word for this count). The independent pronouns 'antum and hum are of course not affected by this condition.

If these two conditions apply, then Nuṣayr uses the long pronouns:

1. If a word beginning with an $m$ directly follows (e.g. wa-min-humū man yaqūl, Q9:49 but not wuğūhu-hum muswaddah, Q39:6o because وجوههم is six letters).

2. If a word beginning with a hamzah directly follows (e.g. wa-id humū 'anfiqū, $\mathrm{Q}_{3} 6: 47$ but not wa-'a-'andarta-hum 'am lam, Q2:6 because و وانذرته 6 or 7 letters).

3. It is directly followed by the last word of the Aya (e.g. wa-bi-l-'āxirati humū yūqinūn\#, Q2:4 but not razaqnā-hum yunfiqūn\#, Q2:3 because رزقهم is six letters)

For the last of these three conditions an intervening one letter word such as $w a$-, $b i$ - or $f a$-is not considered an intervening word, thus one reads $f a-k u b k i b \bar{u}$ fìhā humū wa-l-g̈āwūn\# (Q26:94).

While Qutaybah's treatment is similar, it is less complex. Condition A applies, but B does not. And only conditions 2 and 3 apply, but 1 does not. Moreover, no short words may intervene in the last word of the verse and the pronoun (e.g. mimmā razaqnā-humū yunfiqūn\#, Q2:3 but fa-kubkibū fìha hum wa-l-g̈äwūn\#, Q26:94).

These two practices of transmission require and showcase intimate knowledge of the text, and a condition which would be impossible to achieve in any 
form of natural language. So, for example, verses 5 and 6 of Q107 are read:

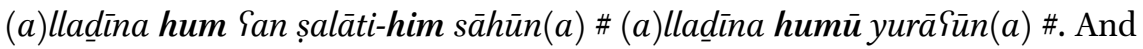
for example Q40:16 yawma hum bārizūn(a) is not read with a long pronoun because $\operatorname{barizu} n(a)$ is only the end of the verse in the Damascene verse count and not in the Kufan verse count (Spitaler 1935, 56).

\subsection{The Choices of the Canonical Readers}

With the large amount of variation found in the readings, many variations of which are difficult to understand as the result of natural language change, one comes to wonder what the reasons for this mixed status would be. It might be tempting to see, for example, Hafṣ' reading of unharmonized - $h u$ in ?ansāni- $h u$ and Salay-hu !l ăh (§ 3.6.4.5) as coming from a report that said "Hafș would recite words such as ?ansāni-hu and Salay-hu !lāh with -hu instead of -hi", and in an overzealous attempt to apply the rule as accurately as possible, the transmitter would have applied it to only the words mentioned, rather than generalize it to its full implication as was intended by our hypothetical report. ${ }^{47}$

However, in most cases I am disinclined towards an interpretation of faulty or incomplete transmission to be the reason for the irregularities that we find to have taken place between the period of the canonical readers and when the readings were first described in detail, as it seems that the transmission from the canonical readers up until Ibn Muğāhid is quite accurate. This can be confirmed independently for several of the readers. While before Ibn Muğāhid we have no extant complete transmissions of the canonical readings, we do have early reports of these readings in works not primarily concerned with the reading traditions.

Al-Farrā? (d. 209AH), a direct student of al-Kisā?ī (d. 189AH), and thus also a younger contemporary of ŠuSbah $(\mathrm{d} .194 \mathrm{AH})$ and a generation removed from Hamzah (d. $156 \mathrm{AH}$ ) often reports on the readings of these three reciters (in the case of ŠuSbah invariably just referred to as the reading of Yāșim (d. $127 \mathrm{AH})$ ) in his Måānī al-Qur?ān and Luġät al-Qur?ān. His reports in these works are

47 Rabin $(1951,99, \S f)$ seems to have understood a report in the generalized sense rather than the specific, as he claims that Hafṣ read without vowel harmony fairly consistently. Something not claimed in the classical literature, to my knowledge. While I have been unable

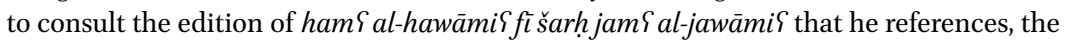
only attestation of Ḥafș in this book indeed discusses his lack of harmony but certainly not as a general rule, but simply the two known places only as discussed in §3.6.4.5. (al-Suyūṭi hamৎ al-hawāmi\}, I, 196). 


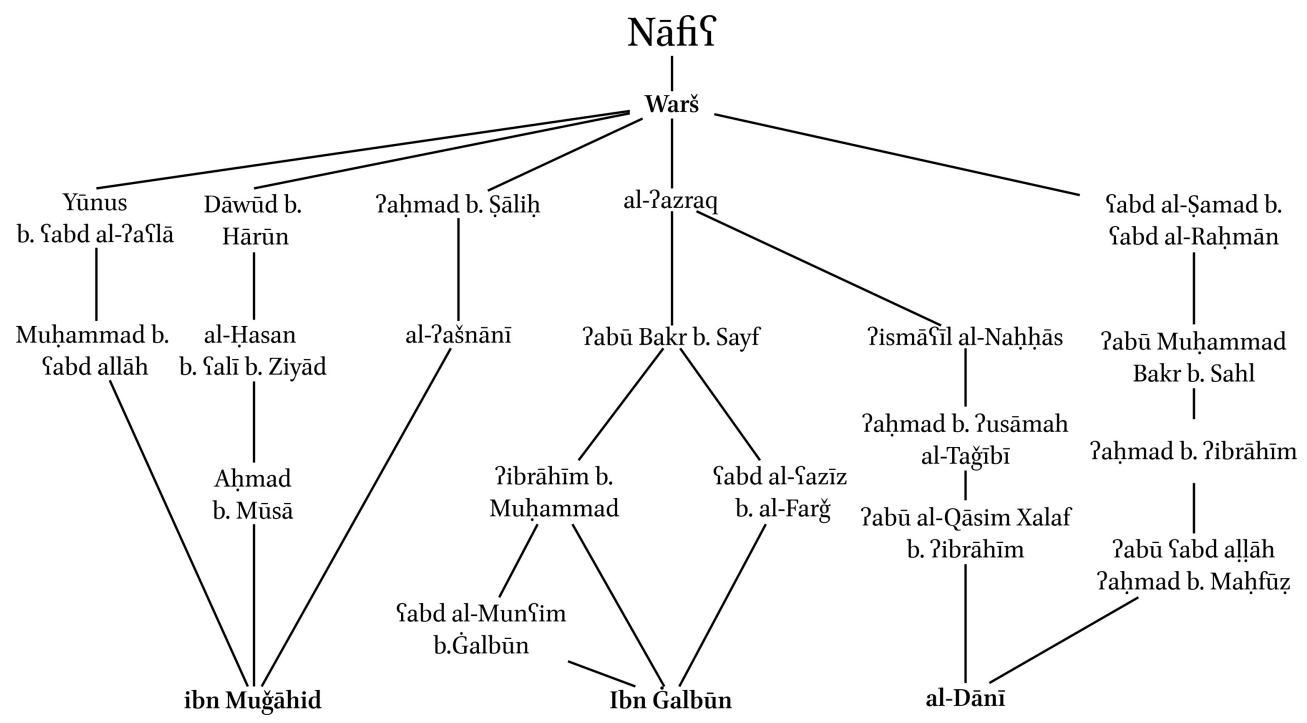

FIGURE 2 Pisnāds of Warš from different medieval authors

almost always in line with what Ibn Muḡāhid reports, while none of his Pis$n \bar{a} d s$ to these readers go through al-Farrā?. This lends significant credibility to the accuracy of the transmission. Likewise, Ibn Muğāhid and later authors like al-Dānī, Ibn Ġalbūn or Ibn al-Ǧazarī frequently have independent paths to the transmitters without this resulting in massive disagreement among these works. ${ }^{48}$

In some cases, we can pinpoint an innovation with accuracy, such as Warš' lengthening of the plural pronouns exclusively before words with a hamzah (§ 3.6.5). Examining the Pisnāds of Ibn Muğāhid (89, 91), Ibn Galbūn (al-tadkirah, $18 \mathrm{f}$.) and al-Dānì (al-taysīr, 11) we see that the three authors have fairly independent transmissions back to Warš, and all invariably report this same conditioning. This leaves little doubt that indeed Warš was the innovator of this system, and not someone further down his transmission path.

In other cases, it is not always possible to be certain whether a transmitter innovated or not. For example, Hafṣ reads the word ra?üf with a long vowel whenever it occurs, whereas ŠuSbah reads ra?uf. Both transmitters trace their reading back to Yāṣim, so how do we decide which reading Yāṣim actually read? We might rely on outside factors, such as the fact that all other Kufans also read

48 The overall soundness of transmission of the readings is affirmed, although not exactly demonstrated, by Nasser $(2013 \mathrm{~b}, 136)$ as well. 
ra?uf to consider Ḥafș' reading to be the innovative one, while ŠuSbah's is the original as it is more typically Kufan. But it is fairly easy to turn that argument on its head: one could argue that Šuibah's reading was influenced by the other Kufans around him, whereas Ḥafș retained the original reading. ${ }^{49}$

Modern Muslim orthodoxy tries to reconcile cases where the transmitters disagree by asserting that the eponymous reader must have taught both options (As-Said 1975, 91-93). While this is often just used as a convenient excuse for resolving the issue of conflicting readings, there is of course no reason to think that an eponymous reader did not, indeed read certain words in different ways on different occasions or changed their mind during their career as teacher. Whatever is the case, specific variants can only seldomly be rationalized as the result of faulty transmission.

When we turn to the eponymous readers themselves, we quickly lose the ability to gain insight into the development of different options. In some cases, eponymous readers stand in a teacher-student relationship such as ?abu Jaffar $\rightarrow$ Nāfí; Ibn Katīir $\rightarrow$ Rabū Yamr; and Ḥamzah $\rightarrow$ al-Kisā̃īi Ḥamzah $\rightarrow$ Sulaym b. Yissā $\rightarrow$ Xalaf. These relationships help us understand similarities between the readers; all these teacher-student relations show up as obvious similarities of specific word choices when we compare their readings (see Sidky forthcoming; Melchert 2008). However, it is difficult to recover any reason for the differences they have in their linguistic systems. Why, for example, do al-Kisā?ī and Xalaf simply apply vowel harmony to Salay-him, Pilay-him and laday-him, unlike Hamzah? Why did their teacher choose to not apply harmony in only those three words?

All of these readers had more teachers than just the canonical readers, and some of the variation and irregularity is probably to be attributed to this fact. Presented with multiple teachers, each teaching different options, a reader was tasked with deciding themselves which form they considered to be the most correct and most eloquent. Such choices would probably not always have been made through purely linguistic reasoning, but the exact methods through which this happened are mostly unrecoverable.

One might envision, for example, the case of Hamzah's unique $i$-umlaut Pimālah of di $i \bar{e} f a n$, that one of the teachers of Hamzah transmitted to him a report that the prophet used to recite "wa-l-yaxša lladìna law takrahü min xalfihim dِuriyyatan ḍifēefan xēfū Salayhum fa-l-yattaqù !̣̣āha wa-l-yaqūlū qawlan

49 This may, in fact, be made plausible by the fact that Ibn Muǧăhid brings a transmission of al-Kisā?ī $\leftarrow$ ŠuSbah that he did in fact read raßū $f$ and not rẩuf, despite al-Kisā?ī reading ra?uf himself (Ibn Muğāhid, 171). 
sadidan (Q4:9)" which could have been an accurate transmission of $i$-umlaut or perhaps the result of the transmitter speaking with affected recitation due to his own dialect having $i$-umlaut. Not wanting to misrepresent this alleged prophetic reading, Hamzah would have piously inserted the $i$-umlaut of $d i \zeta \bar{e}$ fan into his own recitation, without further thinking or analysing the broader implication of $i$-umlaut being present in this word out of conservatism. While such a hypothetical scenario is not necessarily unrealistic, it does not seem possible to recover why a reciter chose the forms he chose, and what other options he had access to.

One interesting and rare case where the tradition gives us a direct piece of insight into the selection procedure of readings is found with Nāfil. His method of constructing his reading is reported by Ibn Muğāhid (61f.), who says that NāfiS said: "I looked to what two among them [his teachers] agreed upon, and I adopted it [in reading], and if any was alone [in reading a certain word], I removed it, until I had constructed this reading made up of these aspects." ${ }^{50}$ Such a method as laid out by Nāfí makes sense of the mixed linguistic nature of this reading, even if the teachers that he drew his data from all had fully regular and natural readings - which they likely did not, as they themselves may have had similar methods of constructing their reading.

From the very earliest transmissions of the reading traditions, we find that they already contain a collection of different dialectal features. Some of these features can be considered clear and conscious innovations, but many of them are likely the result of a similar 'construction' of different features as the parameters of the eloquent Sarabiyyah were being negotiated by different readers. The mixed character did not come about through faulty transmission in between the time that the readers were active and when the readings were canonized. This mixed form seems quite reliably attributable to the eponymous readers that they are said to represent. As can be seen from Nāfif's reported method of constructing his reading, the primary concern of the canonical readers was not to transmit a consistent linguistic system, but rather to construct a reading containing eloquent features by whatever standard they considered it to be eloquent. A standard which, more often than not, was probably not a linguistically motivated one.

50 Fa-nazartu Pilā mā ğtamaSa Salayhi tnāni minhum fa-Paxad̆tuhū, wa-mā šad dun taraktuhū, hattā Pallaftu hädihi l-qirāêata fì hādihi l-ḥurūf. 


\subsection{Conclusion}

In this chapter we have examined the language of the Quranic reading traditions. While it is often accepted as a truism that the language of the Quran is Classical Arabic, actually examining this statement reveals subtleties that cannot be glossed over if we want to examine what the language of the Quran really is. Looking at the language of the reading traditions it is clear that the answer is not so simple. The tradition presents us with 20 different answers to what the language of the Quran really is.

Second, looking closer, we find that none of these readings represent anything like natural language, or in fact any kind of language described by the Arab grammarians. Regular sound changes that are described in great detail by the Arab grammarians fail to apply with any consistency in the Quranic reading traditions. As such, none of the readings can be considered 'dialects of Arabic', nor in fact any form of natural language.

While the reasons for these irregularities are not always recoverable, it is clear that the artificial nature of the readings is not just the result of incomplete or faulty transmission of the 'true' language of the Quran. The readings in many cases embrace artificial features for a certain artistic effect, which suggests a conscious attempt of the readers to beautify their recitation with unusual and exotic features.

Nöldeke $(1910,2)$ already remarked on this well over a century ago, he feels that one can still recover the true language below this, saying that "among these reading traditions there are certain things that were more or less alien to living language. The oriental has the tendency to artificially ornament the solemn recitation of their holy texts; [...] But the real language shines through everywhere." ${ }^{51}$ I believe that Nöldeke's confidence that the real language shines through everywhere is not borne out by the evidence. Due to these artificial features, it is not altogether obvious that we can recover the "language of the Quran" through reflection on the Quranic reading traditions. None of them form a consistent system (as also noted by Nöldeke et al. 2013, 543), and it is unclear which layers of artifice and irregularity one should remove to get to the "true" language of the Quran, and which ones to keep. The early grammarians like Sībawayh and al-Farrā?, active around the same period as the early transmitters of the readers, likewise fail to give a unified answer to what this "real

$51 \quad$ Unter diesen Lesarten ist sicher manches, was der lebenden Sprache mehr oder weniger fremd war. Der Orientale neigt dazu, den feierlichen Vortrag heiliger Texte künstlich zu gestalten; das taten auch die Juden und die Syrer. Aber die wirkliche Sprache blickt doch überall durch. 
language" would have been exactly (see chapter 2 ). So, the gaps that the removal of the "artificial ornaments" would yield—provided we could confidently identify all of them - cannot simply be filled with a unified answer coming from the data of the grammarians.

Moreover, even if it would be somehow possible to filter out from the material of the grammarians which parts of their description represents Nöldeke's "real language", we would still have to accept that the grammarians' conception of this "real language"-living more than 150 years after the rise of Islamwould be an accurate representation of what the "real language" was felt to be at the time of composition. I do not believe that this is convincingly demonstrated by anyone.

What is clear, however, is that contrary to the common conception that the Sarabiyyah is based on eastern dialects, whenever the readers agree on a feature, they primarily converge upon forms that are said to be Hijazi by the Arab grammarians. If anything is to be gained from the readings to inform us about what language the Quran represents, the answer would seem to be that at its core there seems to be traces of a Hijazi dialect, and that this is what shines through if we were to remove Nöldeke's "artificial ornaments".

It seems that the reading traditions cannot give us a more accurate understanding of what the language of the Quran would be, as they are clearly not trying to accurately represent its original language. The only aspect of the Quran that can certainly be projected back to the very beginning of the Islamic period with little to no change is the Quranic Consonantal Text. This therefore functions as the only direct source of the language of the Quran. The QCT as a source of linguistic information will be examined in the next chapter. 